ARTICLE

https://doi.org/10.1038/s41467-019-10028-z

\title{
More efficient North Atlantic carbon pump during the Last Glacial Maximum
}

\author{
J. Yu (i) 1,2, L. Menviel (10 ${ }^{3}$, Z.D. Jin²,4, D.J.R. Thornalley (1) ${ }^{5}$, G.L. Foster ${ }^{6}$, E.J. Rohling (1) 1,6, I.N. McCave (1) ${ }^{7}$, \\ J.F. McManus ${ }^{8}$, Y. Dai ${ }^{1}$, H. Ren (10 ${ }^{9}$, F. He (1) ${ }^{10,11}$, F. Zhang (10 ${ }^{2,12}$, P.J. Chen ${ }^{13}$ \& A.P. Roberts ${ }^{1}$
}

During the Last Glacial Maximum (LGM; 20,000 years ago), the global ocean sequestered a large amount of carbon lost from the atmosphere and terrestrial biosphere. Suppressed $\mathrm{CO}_{2}$ outgassing from the Southern Ocean is the prevailing explanation for this carbon sequestration. By contrast, the North Atlantic Ocean-a major conduit for atmospheric $\mathrm{CO}_{2}$ transport to the ocean interior via the overturning circulation-has received much less attention. Here we demonstrate that North Atlantic carbon pump efficiency during the LGM was almost doubled relative to the Holocene. This is based on a novel proxy approach to estimate air-sea $\mathrm{CO}_{2}$ exchange signals using combined carbonate ion and nutrient reconstructions for multiple sediment cores from the North Atlantic. Our data indicate that in tandem with Southern Ocean processes, enhanced North Atlantic $\mathrm{CO}_{2}$ absorption contributed to lowering ice-age atmospheric $\mathrm{CO}_{2}$.

\footnotetext{
${ }^{1}$ Research School of Earth Sciences, The Australian National University, Canberra, ACT 2601, Australia. ${ }^{2}$ SKLLQG, Institute of Earth Environment, Chinese Academy of Sciences, Xi'an 710061, China. ${ }^{3}$ Climate Change Research Centre, University of New South Wales, Sydney, NSW 2052, Australia. ${ }^{4}$ Open Studio for Oceanic-Continental Climate and Environment Changes, Qingdao National Laboratory for Marine Science and Technology, Qingdao 266061, China. ${ }^{5}$ Department of Geography, University College London, London WC1E 6BT, UK. ${ }^{6}$ Ocean and Earth Science, University of Southampton, National Oceanography Centre, Southampton SO14 3ZH, UK. ${ }^{7}$ Department of Earth Sciences, University of Cambridge, Cambridge CB2 3EQ, UK. ${ }^{8}$ Lamont-Doherty Earth Observatory of Columbia University, 61 Route 9W/PO Box 1000, Palisades, NY 10964-8000, USA. ${ }^{9}$ Department of Geosciences, National Taiwan University, Taipei, Taiwan. ${ }^{10}$ Center for Climatic Research, Nelson Institute for Environmental Studies, University of Wisconsin-Madison, Madison, WI 53706, USA. ${ }^{11}$ College of Earth, Ocean, and Atmospheric Sciences, Oregon State University, Corvallis, OR 97331, USA. ${ }^{12}$ CAS Center for Excellence in Quaternary Science and Global Change, Xi'an 710061, China. ${ }^{13}$ State Key Laboratory of Marine Geology, Tongji University, Shanghai 200092, China. Correspondence and requests for materials should be addressed to J.Y. (email: jimin.yu@anu.edu.au)
} 
T he North Atlantic Ocean $\left(>\sim 35^{\circ} \mathrm{N}\right.$, including the Nordic Seas and Arctic Ocean) is a major atmospheric $\mathrm{CO}_{2}$ sink, which has been mitigating anthropogenic atmospheric $\mathrm{CO}_{2}$ increases ${ }^{1}$. Preindustrial North Atlantic surface water partial pressure of $\mathrm{CO}_{2}\left(p \mathrm{CO}_{2}\right)$ was up to $\sim 100 \mu$ atm lower than the contemporary atmospheric $p \mathrm{CO}_{2}$ of $\sim 280 \mu \mathrm{atm}$, which caused substantial atmospheric $\mathrm{CO}_{2}$ invasion ${ }^{2,3}$. Despite its modest area, the North Atlantic Ocean accounts for at least $\sim 30 \%$ of the global ocean $\mathrm{CO}_{2}$ uptake today and during preindustrial times ${ }^{1,4}$. Over longer timescales, large-scale oceanic carbon sequestration also occurred during Plio-Pleistocene glaciations ${ }^{5-7}$. This is commonly attributed to reduced glacial Southern Ocean $\mathrm{CO}_{2}$ outgassing $6,8,9$, while even the sign of past North Atlantic $\mathrm{CO}_{2}$ uptake efficiency changes remains unconstrained. Here, we present a novel proxy approach to trace atmospheric $\mathrm{CO}_{2}$ invasion in the North Atlantic and thereby evaluate its role in carbon sequestration in ice-age oceans. We find that the last glacial North Atlantic carbon absorption became more efficient, highlighting a critical role of the North Atlantic Ocean in regulating glacial-interglacial atmospheric $\mathrm{CO}_{2}$ changes.

\section{Results}

Air-sea $\mathrm{CO}_{2}$ exchange tracers. Any effect of ocean processes on atmospheric $p \mathrm{CO}_{2}$ must occur via air-sea $\mathrm{CO}_{2}$ exchange. In the North Atlantic, high-nutrient utilization decreases surface-water dissolved inorganic carbon (DIC) and causes surface-water $p \mathrm{CO}_{2}$ to be lower than atmospheric $p \mathrm{CO}_{2}$ (Supplementary Fig. 1). This leads to net air-to-sea $\mathrm{CO}_{2}$ transfer, creating an air-sea exchange signature of DIC $\left(\mathrm{DIC}_{\mathrm{as}}\right)$. DIC $\mathrm{Das}_{\mathrm{as}}$ signals can be distinguished by accounting for within-ocean DIC redistributions that are heavily mediated by biology (Fig. 1). Biological cycling of organic matter depletes DIC and nutrients such as phosphate $\left(\mathrm{PO}_{4}\right)$ in surface waters and enriches them at depth. Seawater mixing also affects DIC and $\mathrm{PO}_{4}$ concentrations in the ocean. Nevertheless, $\mathrm{PO}_{4}$ variations are ultimately determined by biological processes: without biology, $\mathrm{PO}_{4}$ should be the same everywhere in the ocean regardless of ocean circulation (ignoring the small effect from salinity change). Because marine biology incorporates and releases $\mathrm{PO}_{4}$ and DIC in a relatively fixed proportion following Redfield stoichiometry ${ }^{3,10}$ and because $\mathrm{PO}_{4}$ is not affected by air-sea exchange, $\mathrm{PO}_{4}$ can be used to estimate biology-driven withinocean DIC redistributions (Fig. 1). Any within-ocean DIC redistribution associated with $\mathrm{CaCO}_{3}$ cycling can be accounted for using alkalinity (ALK) and nitrate.

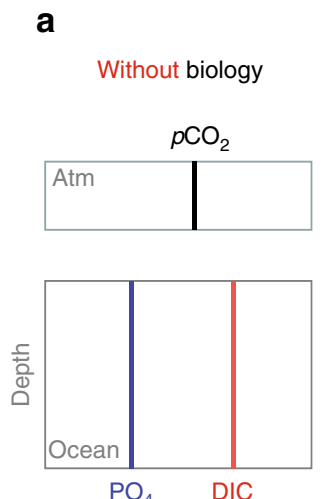

b
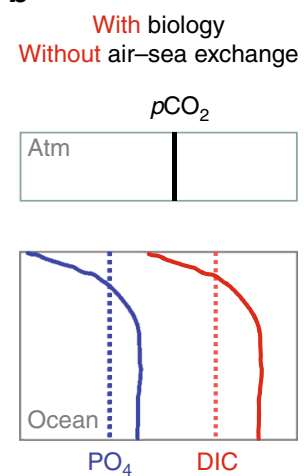

Following the established method ${ }^{3}$ to account for within-ocean DIC redistributions by soft-tissue and $\mathrm{CaCO}_{3}$ cycling, we calculate preindustrial Atlantic DIC $_{\text {as }}$ using the GLODAP dataset $^{2}$ (Fig. 2a). See Methods for details to calculate DIC ${ }_{a s}$. More positive $\mathrm{DIC}_{\mathrm{as}}$ values indicate a greater degree of atmospheric $\mathrm{CO}_{2}$ invasion. At basin-scale, the preindustrial $\mathrm{DIC}_{\mathrm{as}}$ of North Atlantic deep water (NADW) is $\sim 50-80 \mu \mathrm{mol} /$ $\mathrm{kg}$ higher than for Antarctic bottom water (AABW) and Antarctic intermediate water (AAIW). This difference reflects North Atlantic $\mathrm{CO}_{2}$ uptake and Southern Ocean release ${ }^{3,11}$. North Atlantic $\mathrm{CO}_{2}$ absorption is driven by (i) an efficient solubility pump due to strong cooling of northward-flowing Gulf Stream waters and (ii) a strong biological pump associated with high nutrient utilization ${ }^{12-14}$. NADW thus represents an efficient pathway for atmospheric $\mathrm{CO}_{2}$ sequestration ${ }^{6,15}$. Through global deep ocean circulation, $\mathrm{CO}_{2}$ absorbed in the North Atlantic is transported throughout the world ocean ${ }^{1,3}$, with profound implications for the global carbon cycle.

No proxy exists to reconstruct past seawater DIC and ALK at acceptable precision for direct application, so we employ a linked carbonate system parameter for palaeoceanographic studies. Everything else being equal, atmospheric $\mathrm{CO}_{2}$ invasion would decrease seawater carbonate ion concentration $\left(\left[\mathrm{CO}_{3}{ }^{2-}\right]\right)$, because $\mathrm{CO}_{2}$ reacts with carbonate ion to form bicarbonate ${ }^{16}$. We thus develop a new tracer, $\left[\mathrm{CO}_{3}{ }^{2-}\right]_{\text {as }}$, which essentially reflects seawater $\left[\mathrm{CO}_{3}{ }^{2-}\right]$ contrasts for the same biological (i.e., $\mathrm{PO}_{4}$ ) and physical (i.e., temperature-salinity-pressure; T-S-P) conditions (Fig. 2b; see Methods for calculation details). To extract air-sea exchange signals, it is necessary to compare $\left[\mathrm{CO}_{3}{ }^{2-}\right]$ at the same $\mathrm{PO}_{4}-\mathrm{T}-\mathrm{S}-\mathrm{P}$ conditions because we must first remove influences on $\left[\mathrm{CO}_{3}{ }^{2-}\right]$ from (i) within-ocean DIC and ALK redistributions by biology and (ii) $\mathrm{T}-\mathrm{S}-\mathrm{P}$ variations via their effects on $\mathrm{CO}_{2}$ system dissociation constants ${ }^{16}$. In the preindustrial Atlantic, the strong negative correlation between $\left[\mathrm{CO}_{3}{ }^{2-}\right]_{\mathrm{as}}$ and $\mathrm{DIC}_{\mathrm{as}}$ (Fig. 2, Supplementary Fig. 2) indicates that $\left[\mathrm{CO}_{3}{ }^{2-}\right]_{\text {as }}$ variations are affected only by $\mathrm{DIC}_{\mathrm{as}}$, and thus are ultimately linked to air-sea $\mathrm{CO}_{2}$ exchange.

The Gulf Stream is a major NADW source ${ }^{17}$; thus, comparing the $\left[\mathrm{CO}_{3}{ }^{2-}\right]_{\text {as }}$ gradient between the Gulf Stream and NADW can provide a measure of $\mathrm{CO}_{2}$ sequestration intensity during transformation of Gulf Stream waters into NADW. Because Gulf Stream waters are more or less in equilibrium with atmospheric $p \mathrm{CO}_{2}$ from $\sim 10^{\circ} \mathrm{N}$ to $35^{\circ} \mathrm{N}^{1,2}$, the Gulf Stream-NADW $\left[\mathrm{CO}_{3}{ }^{2-}\right]_{\mathrm{as}}$ gradient mainly reflects North Atlantic $\left(>\sim 35^{\circ} \mathrm{N}\right)$ air-sea $\mathrm{CO}_{2}$

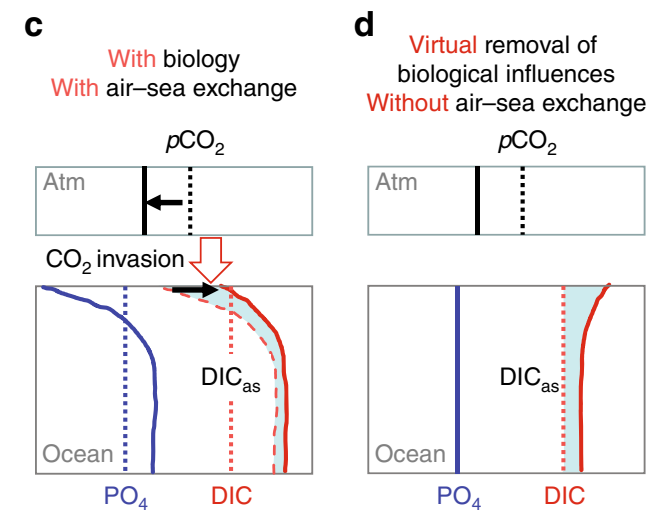

Fig. 1 Concepts to distinguish $\mathrm{DIC}_{\mathrm{as}}$. For simplicity, only $\mathrm{CO}_{2}$ invasion associated with organic matter cycling is considered. In the ocean box, vertical solid and dashed lines (a-d) represent mean $\mathrm{PO}_{4}$ (blue) and DIC (red) in an abiotic ocean (a). Biology redistributes DIC and $\mathrm{PO}_{4}$ following Redfield stoichiometry (curves; b). This decreases surface-ocean $\mathrm{DIC}$ and $p \mathrm{CO}_{2}$, and hence causes air-to-sea $\mathrm{CO}_{2}$ transfer (c). Through mixing and ocean circulation, $\mathrm{CO}_{2}$ invasion raises water-column DIC, i.e., shifting dashed curve (equals the red-solid curve in $\mathbf{b}$ ) to red-solid curve (c). The shaded region in $\mathbf{c}$ represents air-sea exchange $\mathrm{DIC}_{\mathrm{as}}$ signatures. After removing carbon redistribution by biology based on $\mathrm{PO}_{4}$-related curvature of the profiles $(\mathbf{b})$, $\mathrm{DIC}$ as can be revealed by the shaded region in $\mathbf{d}$ 

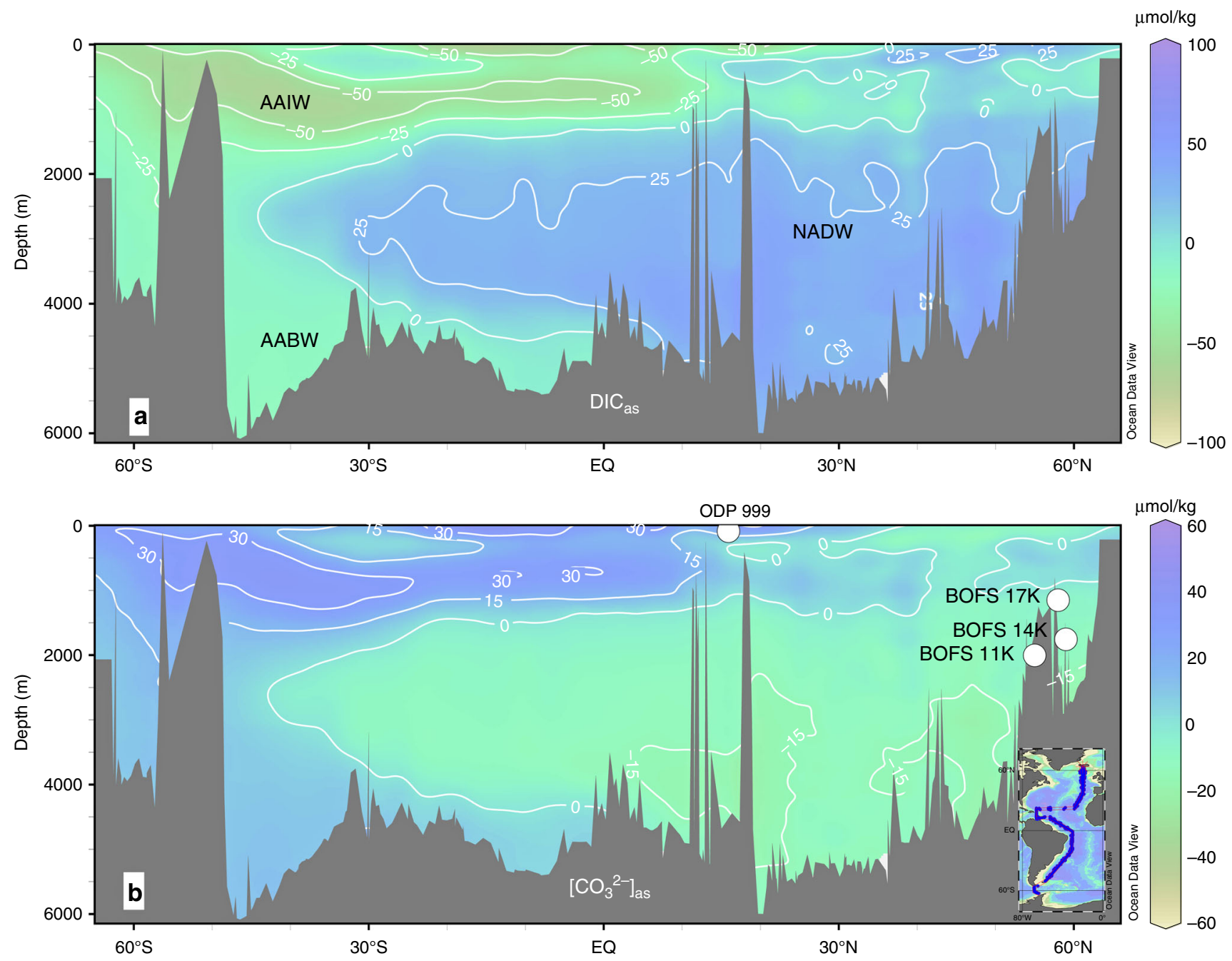

Fig. 2 Preindustrial Atlantic air-sea exchange tracers. a DIC ${ }_{a s}$. b $\left[\mathrm{CO}_{3}{ }^{2-}\right]_{\mathrm{as}}$. Circles represent studied sediment cores. Inset: GLODAP hydrographic data ${ }^{2}$ used to generate the sections ${ }^{96}$. NADW North Atlantic deep water, AABW Antarctic bottom water, AAIW Antarctic intermediate water. See Methods for calculation details

exchange (Supplementary Fig. 3). Physical oceanographers have shown that the path of Gulf Stream waters, rather than being a direct conveyor to the polar North Atlantic, is instead a "corkscrew", where Gulf Stream waters are recirculated south in the subtropical gyre and subduct after being made more dense by air-sea heat loss (e.g., refs. ${ }^{18,19}$ ). However, our interest lies in net $\mathrm{CO}_{2}$ uptake by the North Atlantic region, and variations in spatial pathways from Gulf Stream to NADW formation sites ${ }^{18,19}$ should not significantly complicate our conclusion. The greater the $\left[\mathrm{CO}_{3}{ }^{2-}\right]_{\text {as }}$ gradient between Gulf Stream and NADW (instead of their absolute $\left[\mathrm{CO}_{3}{ }^{2-}\right]_{\text {as }}$ values), the more efficient air-sea $\mathrm{CO}_{2}$ absorption by the North Atlantic. Linked to large-scale overturning circulation, Gulf Stream-NADW $\left[\mathrm{CO}_{3}{ }^{2-}\right]_{\text {as }}$ gradient changes regulate long-term $\mathrm{CO}_{2}$ sequestration into the deep ocean.

Downcore reconstructions. Next, we reconstruct past Gulf Stream-NADW $\left[\mathrm{CO}_{3}{ }^{2-}\right]_{\text {as }}$ gradients to investigate North Atlantic carbon pump efficiency during the LGM (18-27 ka). Previous work suggests that most of North Atlantic subtropical gyre water circulates through the Caribbean Sea before being transported to the subpolar North Atlantic via the Gulf Stream ${ }^{20}$. We, therefore, use Caribbean Sea ODP Site $999\left(12.8^{\circ} \mathrm{N}, 78.7^{\circ} \mathrm{W}\right)$ to constrain past Gulf Stream physicochemical conditions (Fig. 3, Supplementary Figs. 4 and 5). The feasibility of using ODP Site 999 to reflect the first-order Gulf Stream carbonate chemistry changes between the Holocene and LGM is supported by observations that (i) Caribbean surface waters have similar $\left[\mathrm{CO}_{3}{ }^{2-}\right]_{\text {as }}$ values to hydrographic sites located within Gulf Stream during the preindustrial (Supplementary Fig. 3), and (ii) cores from the broader western subtropical Atlantic show comparable Holocene and LGM $\left[\mathrm{CO}_{3}{ }^{2-}\right]_{\text {as }}$ signatures as those from ODP 999 (Supplementary Fig. 6). Surface-water T and S are estimated from Globigerinoides ruber $\mathrm{Mg} / \mathrm{Ca}$ and sea level fluctuations, respectively ${ }^{21,22}$. Previously published G. ruber $\delta^{11} \mathrm{~B}$ (ref. ${ }^{21}$ ) is used to calculate surface-water $\mathrm{pH}$, while ALK is estimated from $\mathrm{S}$ using the modern relationship between $\mathrm{S}$ and $\mathrm{ALK}^{21,22}$. Along with T, $\mathrm{S}$, and ALK estimates, $\mathrm{pH}$ is then used to calculate surface-water $\left[\mathrm{CO}_{3}{ }^{2-}\right]$ and DIC. Given the constraint from $\mathrm{pH}$, seawater ALK and DIC must vary systematically within the ocean carbonate system (Supplementary Fig. 5). This allows precise estimation of $\left[\mathrm{CO}_{3}{ }^{2-}\right]$, because even large ALK uncertainties $(100 \mu \mathrm{mol} / \mathrm{kg} ; \pm 2 \sigma$, used throughout) only have a minor effect on $\left[\mathrm{CO}_{3}{ }^{2-}\right](\sim 14 \mu \mathrm{mol} / \mathrm{kg})$. Given its oligotrophic setting, past surface-water $\mathrm{PO}_{4}$ at ODP 999 is assumed to be zero' $2,21,22$.

Three cores are used to reconstruct deep-water conditions of northern-sourced waters (Fig. 3). BOFS $17 \mathrm{~K}\left(58^{\circ} \mathrm{N}, 16.5^{\circ} \mathrm{W}\right.$, 

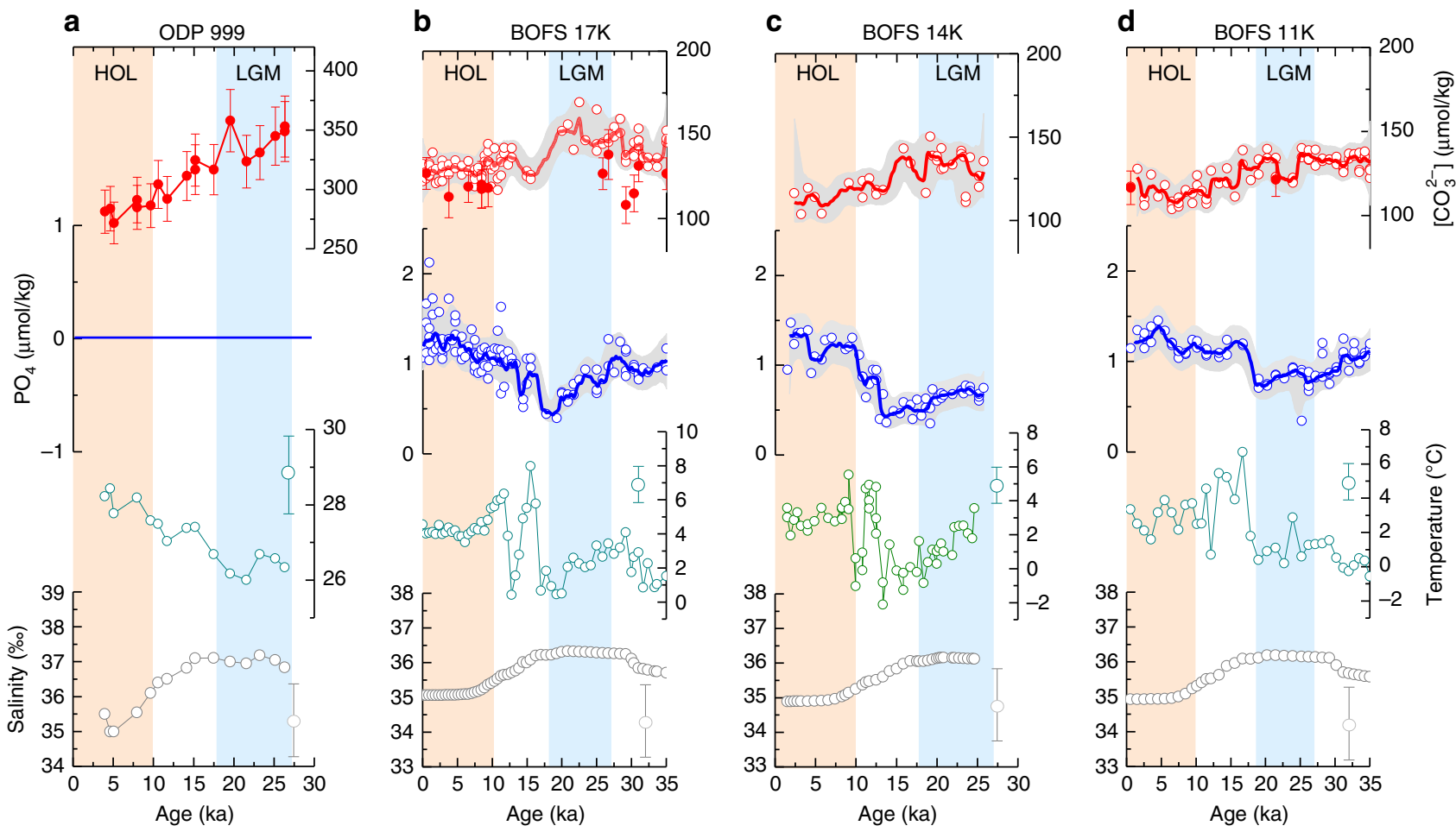

Fig. 3 Down core reconstructions. a ODP 999. b BOFS $17 \mathrm{~K}$. c BOFS $14 \mathrm{~K}$. d BOFS $11 \mathrm{~K}$. Seawater $\left[\mathrm{CO}_{3}{ }^{2-}\right.$ ] values are derived from benthic B/Ca (empty circles) and $\delta^{11} \mathrm{~B}$ (solid circles). Light gray envelopes and error bars: $2 \sigma$. Note different $y$-scales for surface- (ODP 999) and deep-water (BOFS cores) reconstructions. See Methods for reconstruction details

$1150 \mathrm{~m})$ and BOFS $14 \mathrm{~K}\left(58.6^{\circ} \mathrm{N}, 19.4^{\circ} \mathrm{W}, 1756 \mathrm{~m}\right)$ are located close to the previously surmised center of Glacial North Atlantic intermediate water (GNAIW) ${ }^{23}$, while BOFS $11 \mathrm{~K}\left(55.2^{\circ} \mathrm{N}, 20.4^{\circ}\right.$ $\mathrm{W}, 2004 \mathrm{~m}$ ) is thought to be affected by glacial Nordic Sea overflows $^{24}$. We employ benthic foraminiferal $\delta^{11} \mathrm{~B}$ and $\mathrm{B} / \mathrm{Ca}$ to reconstruct deep-water $\left[\mathrm{CO}_{3}{ }^{2-}\right]$ with an uncertainty of $\sim 10$ $\mu \mathrm{mol} / \mathrm{kg}^{25} . \delta^{11} \mathrm{~B}$ and $\mathrm{B} / \mathrm{Ca}$ give consistent downcore $\left[\mathrm{CO}_{3}{ }^{2-}\right]$ reconstructions. Benthic $\mathrm{Cd} / \mathrm{Ca}$ is used to estimate deep-water $\mathrm{Cd}$ and $\mathrm{PO}_{4}$ based on an established approach (Supplementary Fig. 7) 26,27 . Past deep-water T and S changes are estimated from foraminiferal $\delta^{18} \mathrm{O}$ and sea level fluctuations; use of other methods negligibly affects our conclusion. In total, we present 180 new measurements for benthic foraminiferal $\delta^{11} \mathrm{~B}, \mathrm{~B} / \mathrm{Ca}$, and $\mathrm{Cd} / \mathrm{Ca}$. Details of core materials, methods, new and compiled data, and fully propagated uncertainties are given in Methods and Supplementary Data 1-9.

A pragmatic recipe to estimate $\left[\mathrm{CO}_{3}{ }^{2-}\right]_{\text {as }}$ change. Surface-water $\left[\mathrm{CO}_{3}{ }^{2-}\right]$ at ODP 999 is $\sim 150 \mu \mathrm{mol} / \mathrm{kg}$ higher than deep-water values at BOFS cores (Fig. 3), but this $\left[\mathrm{CO}_{3}{ }^{2-}\right]$ contrast includes influences from physical (via dissociation constants) and biological (via within-ocean DIC and ALK redistributions) changes in addition to any air-sea $\mathrm{CO}_{2}$ changes between surface and deep waters. Below, we present a pragmatic recipe to estimate $\left[\mathrm{CO}_{3}{ }^{2-}\right]_{\text {as }}$ gradients between water masses. We take advantage of well-defined sensitivities of $\left[\mathrm{CO}_{3}{ }^{2-}\right]$ to T-S-P (Fig. 4) to calculate normalized seawater $\left[\mathrm{CO}_{3}{ }^{2-}\right]\left(\left[\mathrm{CO}_{3}{ }^{2-}\right]_{\mathrm{Norm}}\right)$ at conditions of $T=3{ }^{\circ} \mathrm{C}, S=35 \%$, and $P=2500 \mathrm{dbar}$ (Methods). Any variation in $\mathrm{T}-\mathrm{S}-\mathrm{P}$ would affect seawater $\left[\mathrm{CO}_{3}{ }^{2-}\right]$ via (i) changing $\mathrm{CO}_{2}$ system dissociation constants, and (ii) altering the solubility pump and thereby air-sea exchange component $\mathrm{CO}_{2}$ concentrations in seawater. Calculation of $\left[\mathrm{CO}_{3}{ }^{2-}\right]_{\mathrm{Norm}}$ only corrects for influences from (i), without affecting any air-sea $\mathrm{CO}_{2}$ signal.
After normalization to constant T-S-P conditions and assuming no net air-sea exchange, biological activity drives changes in both $\left[\mathrm{CO}_{3}{ }^{2-}\right]_{\text {Norm }}$ and $\mathrm{PO}_{4}$ along the biological trend (green curves in Fig. 5; Methods). Note that along a certain biological trend, seawater $\left[\mathrm{CO}_{3}{ }^{2-}\right]_{\text {Norm }}$ and $\mathrm{PO}_{4}$ are only affected by within-ocean DIC and ALK redistributions (Fig. 1b). A net air-sea $\mathrm{CO}_{2}$ change would cause changes in $\left[\mathrm{CO}_{3}{ }^{2-}\right]_{\text {Norm }}$ and $\mathrm{PO}_{4}$ across biological curves. At the same $\mathrm{PO}_{4},\left[\mathrm{CO}_{3}{ }^{2-}\right]_{\text {Norm }}$ contrasts reflect $\left[\mathrm{CO}_{3}{ }^{2-}\right]_{\text {as }}$ gradients due to air-sea $\mathrm{CO}_{2}$ exchange between water masses.

A plot of $\left[\mathrm{CO}_{3}{ }^{2-}\right]_{\mathrm{Norm}}$ vs. $\mathrm{PO}_{4}$ greatly facilitates investigation of air-sea $\mathrm{CO}_{2}$ exchange from combined $\left[\mathrm{CO}_{3}{ }^{2-}\right]$ and $\mathrm{PO}_{4}$ measurements/reconstructions. Compared to the biological trend, preindustrial North Atlantic surface waters have a steeper trend (Fig. 5a), which reflects $\mathrm{CO}_{2}$ absorption during northward transport. Deep-water data lie on a shallower trend, consistent with mixing between low- $\left[\mathrm{CO}_{3}^{2-}\right]_{\text {as }}$ (high $\mathrm{DIC}_{\mathrm{as}}$ ) NADW and high- $\left[\mathrm{CO}_{3}{ }^{2-}\right]_{\text {as }}$ (low DIC as ) AABW in the deep Atlantic (Fig. 2).

For our downcore reconstructions, benthic $\mathrm{Cd} / \mathrm{Ca}$ suggests that deep-waters at the BOFS sites had $\mathrm{PO}_{4}$ values of $\sim 1.2$ and $\sim 0.8$ $\mu \mathrm{mol} / \mathrm{kg}$ during the Holocene and LGM, respectively (Fig. 5b; Supplementary Fig. 8). Assuming no air-sea $\mathrm{CO}_{2}$ exchange, $\left[\mathrm{CO}_{3}{ }^{2-}\right]_{\text {Norm }}$ of ODP 999 surface waters at elevated $\mathrm{PO}_{4}$ due to biological processes can be estimated straightforwardly using the $H \rightarrow H^{\prime}$ and $G \rightarrow G^{\prime}$ trajectories in Fig. $5 b$ for the Holocene and LGM, respectively. For the Holocene, ODP $999\left[\mathrm{CO}_{3}{ }^{2-}\right]_{\mathrm{Norm}}$ is $\sim 56 \pm 8 \mu \mathrm{mol} / \mathrm{kg}$ higher than $\left[\mathrm{CO}_{3}{ }^{2-}\right]_{\text {Norm }}$ of BOFS cores at $\mathrm{PO}_{4}=1.2 \mu \mathrm{mol} / \mathrm{kg}$. For the LGM, ODP $999\left[\mathrm{CO}_{3}{ }^{2-}\right]_{\mathrm{Norm}}$ is $\sim 114 \pm 9 \mu \mathrm{mol} / \mathrm{kg}$ higher than $\left[\mathrm{CO}_{3}{ }^{2-}\right]_{\text {Norm }}$ of BOFS cores at $\mathrm{PO}_{4}=0.8 \mu \mathrm{mol} / \mathrm{kg}$. This suggests a Holocene-to-LGM increase of $\sim 58 \pm 12 \mu \mathrm{mol} / \mathrm{kg}$ in the ODP $999-$ BOFS $\left[\mathrm{CO}_{3}{ }^{2-}\right]_{\text {as }}$ gradient.

We also present a second approach to calculate $\left[\mathrm{CO}_{3}{ }^{2-}\right]_{\mathrm{as}}$ gradients, which involves frequent use of the $\mathrm{CO}_{2}$ sys program ${ }^{28}$ and intermediate-step ALK and DIC parameters (Supplementary Note 1; Supplementary Figs. 9 and 10). The approach gives 
a

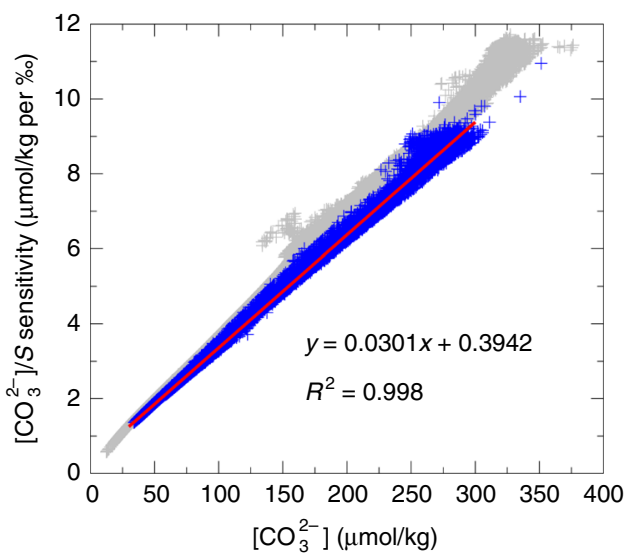

C

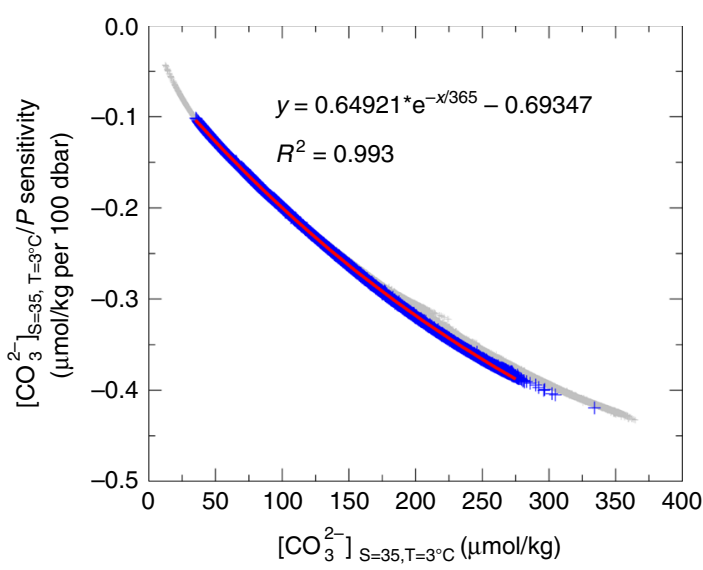

e

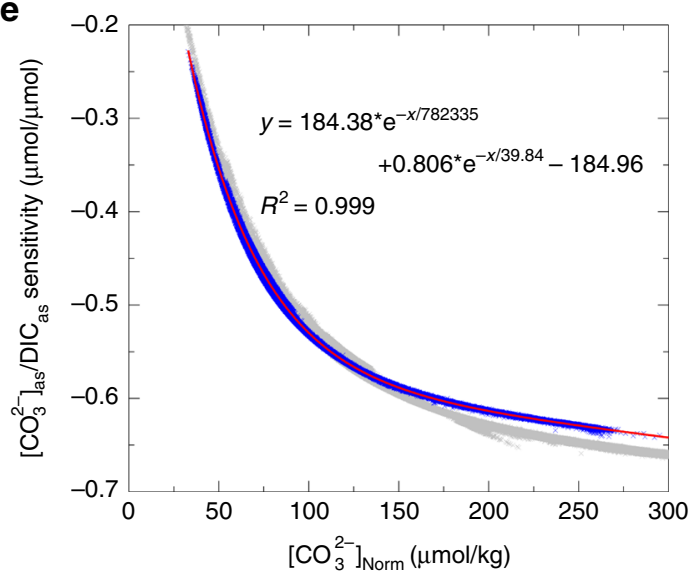

b
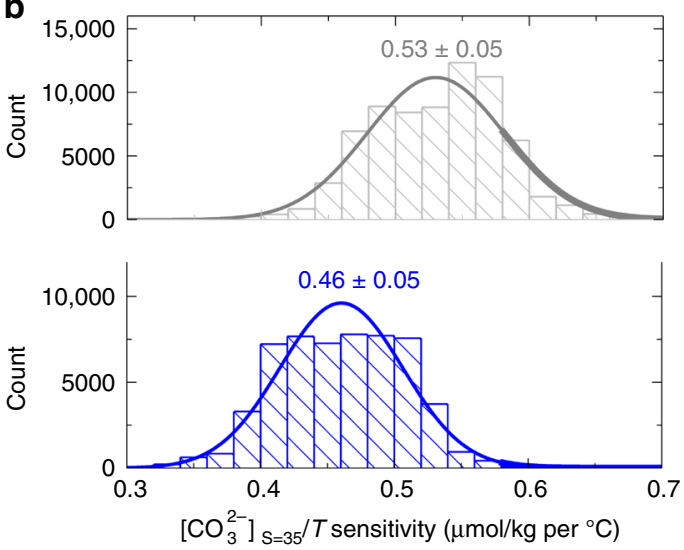

d

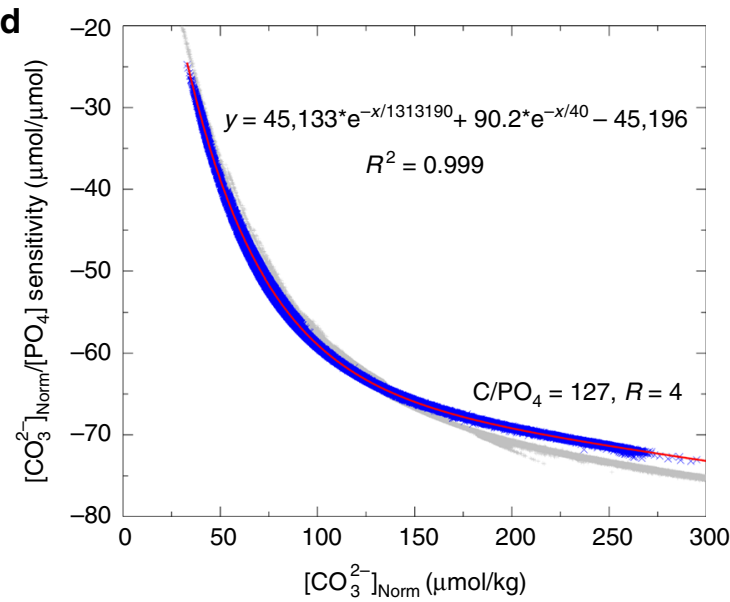

Fig. 4 Carbonate system sensitivities to various changes. a Salinity effect. b Temperature effect. c Pressure effect. d Biological effect. e Air-sea $\mathrm{CO}_{2}$ exchange effect. Calculations are based on $\operatorname{GLODAP}^{2}(n=55,399$; blue) and a LGM output from LOVECLIM 58 ( $n=71,768$; gray). For a-d, calculations assume no net air-sea $\mathrm{CO}_{2}$ change. Best fits of data are shown by red curves. See Methods for calculation details

similar results as the above pragmatic recipe, because both methods are essentially based on the same principle, which is to compare $\left[\mathrm{CO}_{3}{ }^{2-}\right]$ of water masses at the same physical and biological conditions.

Enhanced $\mathrm{CO}_{2}$ uptake in the glacial North Atlantic. What caused the greater ODP $999-\mathrm{BOFS}\left[\mathrm{CO}_{3}{ }^{2-}\right]_{\text {as }}$ gradient during the LGM? We consider influences from biogenic matter composition variations, surface-water $\mathrm{ALK}$ and $\mathrm{PO}_{4}$ changes, ocean circulation changes, and North Atlantic air-sea exchange. In Fig. 5, we have used a soft-tissue Redfield $\mathrm{C} / \mathrm{PO}_{4}$ of 127 and a rain ratio $\left(R,=\mathrm{C}_{\text {organic }}: \mathrm{C}_{\mathrm{CaCO}_{3}}\right)$ of 4 (refs. ${ }^{3,10,29,30}$ ) to predict the biological trend. Raising $\mathrm{LGM} \mathrm{C/PO}$ to 140 (the high end value in today's North Atlantic ${ }^{30}$ ) and $R$ to 8 (doubling of the modern value) could lower the LGM $\left[\mathrm{CO}_{3}{ }^{2-}\right]_{\text {as }}$ gradient by $\sim 16 \mu \mathrm{mol} / \mathrm{kg}$ (Supplementary Fig. 15), still leaving $\sim 42 \mu \mathrm{mol} / \mathrm{kg}\left[\mathrm{CO}_{3}{ }^{2-}\right]_{\text {as }}$ gradient increase to be explained by other processes. Evidence for such large biological changes is lacking. Importantly, any increase in $\mathrm{C} / \mathrm{PO}_{4}$ and $R$ would implicitly sequester more atmospheric $\mathrm{CO}_{2}$ via an enhanced soft-tissue pump and weakened carbonate pump ${ }^{15}$. Inclusion of a whole ocean ALK inventory change ${ }^{6}$ or any increased glacial surface-water $\mathrm{PO}_{4}$ at ODP 999 

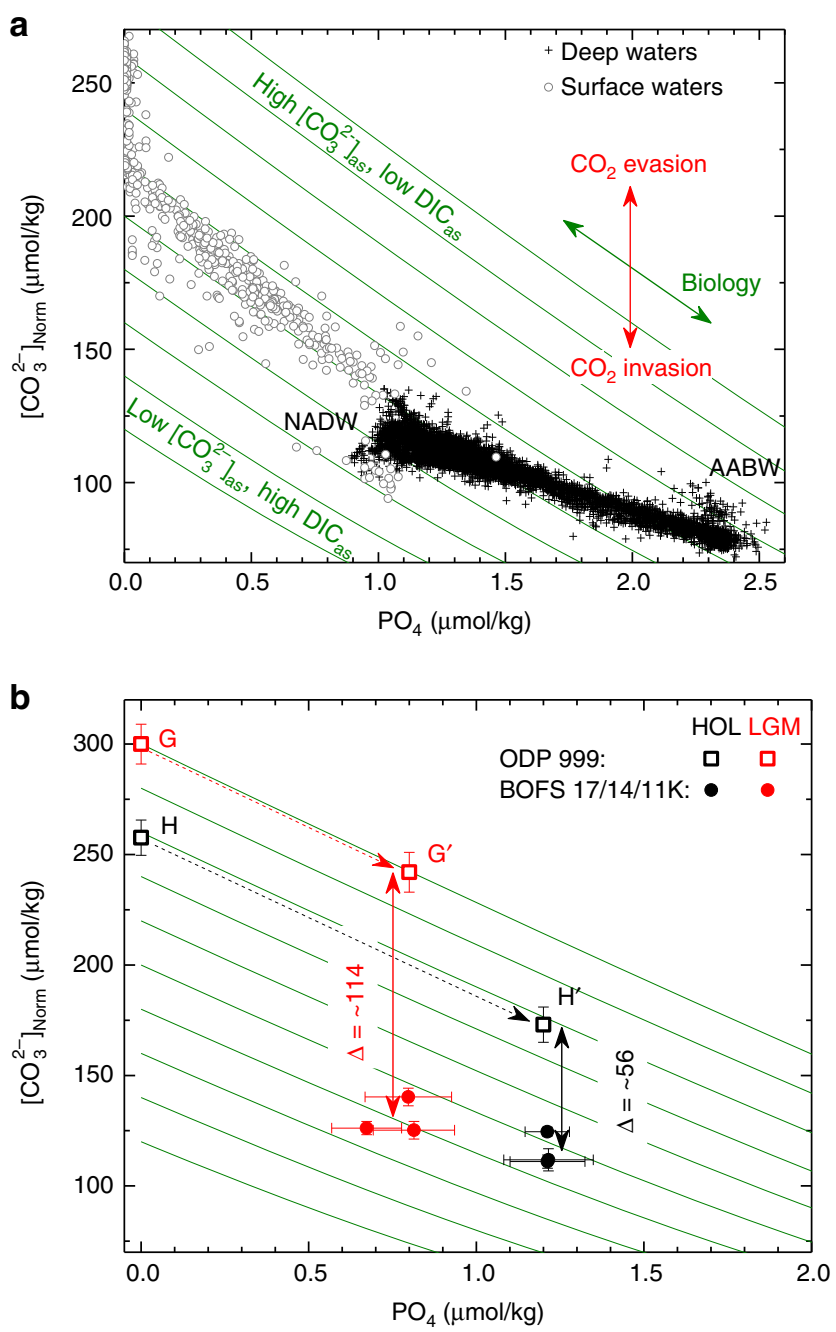

Fig. $5\left[\mathrm{CO}_{3}{ }^{2-}\right]_{\text {Norm }}$ vs. $\mathrm{PO}_{4}$. a Preindustrial Atlantic surface $(<100 \mathrm{~m}$, north of $\left.10^{\circ} \mathrm{N}\right)$ and deep $\left(>1000 \mathrm{~m}, 65^{\circ} \mathrm{N}-65^{\circ} \mathrm{S}\right)$ water data ${ }^{2}$. b Holocene and LGM data. Error bars, $2 \sigma$

would raise the LGM $\left[\mathrm{CO}_{3}{ }^{2-}\right]_{\text {as }}$ gradient (Supplementary Figs. 16 and 17).

Regarding ocean circulation changes, most AAIW upwells in the tropics and less than $\sim 25 \%$ of today's NADW is fed directly by AAIW without surfacing at low latitudes ${ }^{17}$. Northward AAIW transport is thought to have been reduced substantially in the glacial Atlantic ${ }^{23,31-33}$ in the face of vigorous GNAIW production ${ }^{34}$. Assuming a constant total carbon uptake by the North Atlantic, a complete shutdown of AAIW contribution would only raise the ODP $999-\mathrm{BOFS}\left[\mathrm{CO}_{3}{ }^{2-}\right]_{\text {as }}$ gradient by $\sim 30 \%$, which is much smaller than the $\sim 100 \%$ increase from the Holocene $(\sim 56 \mu \mathrm{mol} / \mathrm{kg})$ to LGM $(\sim 114 \mu \mathrm{mol} / \mathrm{kg})$ (Fig. $5 b)$. Any increased mixing of glacial AABW at BOFS sites would reduce the ODP $999-$ BOFS $\left[\mathrm{CO}_{3}{ }^{2-}\right]_{\text {as }}$ gradient during the LGM. Given the proximity of our deep-water sites to the core of GNAIW and Nordic Sea overflow waters $23,24,31,35,36$, the larger LGM $\left[\mathrm{CO}_{3}{ }^{2-}\right]_{\text {as }}$ gradient between ODP 999 and BOFS cores likely reflects a greater $\mathrm{DIC}_{\mathrm{as}}$ increase from Gulf Stream to GNAIW. North Atlantic $\mathrm{CO}_{2}$ invasion was responsible for the preindustrial Gulf Stream-NADW $\left[\mathrm{CO}_{3}{ }^{2-}\right]_{\text {as }}$ gradient (Fig. 2). Therefore, we ascribe the increased ODP $999-\mathrm{BOFS}\left[\mathrm{CO}_{3}{ }^{2-}\right]_{\text {as }}$ gradient during the LGM to more efficient atmospheric $\mathrm{CO}_{2}$ uptake via air-sea exchange and subsequent transport to at least

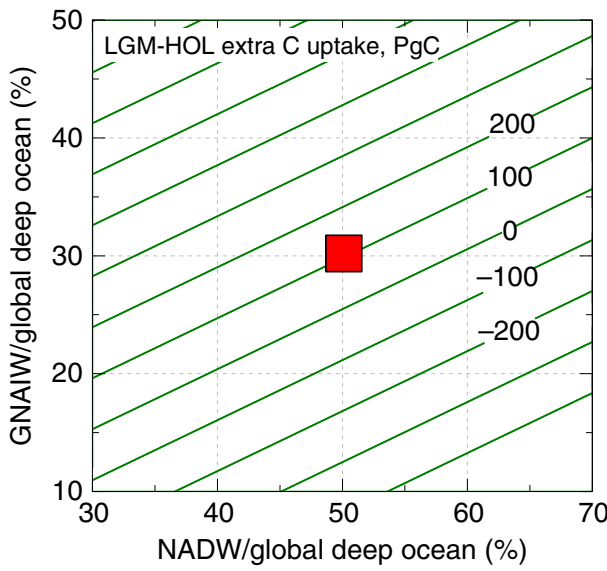

Fig. 6 North Atlantic $\mathrm{CO}_{2}$ budget. The LGM-Holocene extra carbon uptake is based on Holocene-to-LGM DIC as increase of $91 \mu \mathrm{mol} / \mathrm{kg}$. The large red square represents our best estimate of $\sim 100 \mathrm{PgC}$, assuming that NADW and GNAIW occupied $\sim 50 \%$ and $\sim 30 \%$ of the global deep ocean $(>1 \mathrm{~km})$, respectively $35,36,38,39$. See Methods for calculation details

$\sim 2 \mathrm{~km}$ depth (BOFS $11 \mathrm{~K}$ core depth) in the glacial North Atlantic.

Quantification of North Atlantic $\mathrm{CO}_{2}$ uptake. With reconstructed ODP $999-\mathrm{BOFS}\left[\mathrm{CO}_{3}{ }^{2-}\right]_{\text {as }}$ gradients, we further quantify North Atlantic air-sea $\mathrm{CO}_{2}$ absorption changes between the Holocene and LGM. $\left[\mathrm{CO}_{3}{ }^{2-}\right]_{\mathrm{as}} / \mathrm{DIC}_{\mathrm{as}}$ sensitivities can be precisely estimated (Fig. 4e), making $\left[\mathrm{CO}_{3}{ }^{2-}\right]_{\text {as }}$ gradients a useful proxy to calculate $\mathrm{DIC}_{\mathrm{as}}$ changes. The $58 \pm 12 \mu \mathrm{mol} / \mathrm{kg}$ Holoceneto-LGM $\left[\mathrm{CO}_{3}{ }^{2-}\right]_{\text {as }}$ increase (Fig. 5b) indicates a DIC $\mathrm{Cas}_{\text {as }}$ increase of $91 \pm 20 \mu \mathrm{mol} / \mathrm{kg}$ due to enhanced North Atlantic air-sea $\mathrm{CO}_{2}$ absorption (Methods). Compared to the preindustrial Gulf Stream-NADW $\mathrm{DIC}_{\text {as }}$ gradient of $\sim 90 \mu \mathrm{mol} / \mathrm{kg}$ (Fig. 2, Supplementary Fig. 3), this suggests a doubling of $\mathrm{CO}_{2}$ uptake efficiency in the LGM North Atlantic.

Beside $\mathrm{DIC}_{\mathrm{as}}$ gradient changes, which indicate air-sea $\mathrm{CO}_{2}$ uptake efficiency, knowledge of northern-sourced-water volumes in the global deep ocean is required to determine total North Atlantic carbon sequestration. Figure 6 shows the total extra carbon absorbed by the LGM North Atlantic for a range of northern-sourced-water volumes (Methods). Sedimentary $\mathrm{Pa} / \mathrm{Th}$, radiocarbon, neodymium isotopes, and paired benthic $\mathrm{Cd} / \mathrm{Ca}-$ $\delta^{13} \mathrm{C}$ suggest ${ }^{32,34,35,37}$ vigorous glacial northern-sourced intermediate water production and subsequent transport to the remaining world ocean. Based on previous estimates ${ }^{35,36,38,39}$, we tentatively assume that NADW- and GNAIW-derived waters occupy $\sim 50 \%$ and $\sim 30 \%$, respectively, of the global deep ocean volume $\left(1 \times 10^{18} \mathrm{~m}^{3}\right.$ for $\left.>1 \mathrm{~km}\right)$. In this case, our $\sim 91 \mu \mathrm{mol} / \mathrm{kg}$

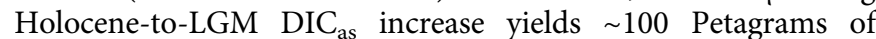
carbon $\left(\mathrm{PgC} ; 1 \mathrm{Pg}=1 \times 10^{15} \mathrm{~g}\right)$ greater $\mathrm{CO}_{2}$ sequestration by the LGM North Atlantic (Fig. 6; Methods). To maintain similar total carbon uptake between the Holocene and LGM, GNAIW would need to be less than $~ 50 \%$ of NADW in volume, which we consider unlikely given evidence for intensive GNAIW export to the global ocean ${ }^{23,32,34,35,37}$. We acknowledge uncertainties associated with our calculations, and encourage future work to better constrain volumes and carbonate chemistry changes of various water masses in the past.

\section{Discussion}

Previous work ${ }^{40-42}$ has tried to constrain air-sea $\mathrm{CO}_{2}$ exchange by reconstructing surface conditions. This requires reconstructions of the air-sea $\mathrm{pCO}_{2}$ difference (influenced by $\mathrm{T}, \mathrm{S}$, and nutrient 
utilization), the gas transfer velocity (a power function of wind speed), solubility of $\mathrm{CO}_{2}$ in seawater (mainly affected by $\mathrm{T}$ ), and the area and contact time of surface waters available for air-sea exchange ${ }^{1}$. Sea ice $\operatorname{cover}^{43}$ possibly expanded, reducing glacial North Atlantic $\mathrm{CO}_{2}$ absorption. A larger LGM meridional surface temperature gradient ${ }^{43,44}$ would enhance the North Atlantic solubility pump $^{13}$. Existing planktonic $\delta^{15} \mathrm{~N}$ and $\mathrm{Cd} / \mathrm{Ca}$ data $^{40,45}$ show conflicting results regarding the glacial North Atlantic nutrient conditions, perhaps due to complications associated with surfacewater proxies and spatial/seasonal nutrient variations in the North Atlantic. A decreased preformed nutrient in the glacial North Atlantic might be inferred from a lower GNAIW $\mathrm{PO}_{4}$ (Fig. 3), but faster ventilation and/or reduced glacial AAIW could also cause a nutrient decline in GNAIW $23,34,46$. Little is known about past wind intensity and air-sea contact time changes. Consequently, potential North Atlantic glacial $\mathrm{CO}_{2}$ invasion remains poorly understood. Bypassing the necessity to reconstruct surface-water conditions for which some proxies are still lacking (e.g., wind), our new approach, to our knowledge, offers the first proxy-based quantitative estimate of air-sea $\mathrm{CO}_{2}$ uptake efficiency in the glacial North Atlantic.

In contrast to previous calculations ${ }^{47-49}$ which concern combined biological (i.e., within-ocean DIC redistribution) and air-sea exchange carbon changes (Fig. 1c), our total North Atlantic carbon uptake estimate only represents the net air-sea $\mathrm{CO}_{2}$ change that is more directly relevant to atmospheric and terrestrial carbon inventory variations. Our estimated $\sim 100 \mathrm{PgC}$ sequestration constitutes $\sim 15 \%$ of the Holocene-LGM $\sim 600$ PgC change associated with the atmosphere $(\sim 200 \mathrm{PgC})$ and terrestrial biosphere $(\sim 400 \mathrm{PgC})^{5,6}$. Given this global carbon budget context, our work reinforces the role of other polar regions (e.g., Southern Ocean) in controlling the glacial-interglacial carbon cycle. However, if there were no efficiency enhancement for the LGM North Atlantic, a $40 \%$ shrinkage of NADW volume would decrease air-sea component $\mathrm{CO}_{2}$ sequestration by $\sim 240 \mathrm{PgC}$ in the deep ocean (Methods). Therefore, by overcoming this opposing "volume effect", the improved glacial North Atlantic efficiency increased DIC ${ }_{\text {as }}$ values of northern-sourced deep waters (termed the "endmember effect") and thereby contributed substantially to air-sea $\mathrm{CO}_{2}$ sequestration in the LGM deep ocean.

Atmospheric $p \mathrm{CO}_{2}$ is controlled by both $\mathrm{CO}_{2}$ gains (e.g., via Southern Ocean outgassing) and losses (e.g., via North Atlantic absorption $)^{2,3,11}$. Growing evidence indicates that processes outside the Southern Ocean may have affected past atmospheric $\mathrm{CO}_{2}$ variations ${ }^{50-52}$. Our proxy-based results indicate that the North Atlantic $\mathrm{CO}_{2}$ pump efficiency during the LGM was almost doubled relative to the Holocene. This increased efficiency and associated "endmember effect" effectively outcompeted the opposing "volume effect" due to any shrinkage of northernsourced deep waters in the world ocean. In addition to the wellrecognized role of reduced outgassing in the Southern Ocean $^{6,8,9,47,53,54}$, we therefore suggest that variations in the uptake and sequestration of atmospheric $\mathrm{CO}_{2}$ via the North Atlantic Ocean were important contributors to glacial/interglacial carbon cycling.

\section{Methods}

$\mathbf{C O}_{\mathbf{2}}$ system calculations. For both the preindustrial ocean and down-core $\mathrm{CO}_{2}$ system calculations, seawater carbonate system variables were calculated using the $\mathrm{CO}_{2}$ sys.xls program ${ }^{28}$ with dissociation constants $K_{1}$ and $K_{2}$ according to Mehrbach et al. ${ }^{55}$ and $K_{\mathrm{SO}_{4}}$ according to Dickson ${ }^{56}$. Seawater total boron concentration was calculated from the boron-salinity relationship of Lee et al. ${ }^{57}$. For the GLODAP dataset, the anthropogenic $\mathrm{CO}_{2}$ contribution was subtracted from the measured DIC to obtain preindustrial DIC values ${ }^{2}$.

Preindustrial Atlantic DIC as and $\left[\mathbf{C O}_{3}{ }^{2-}\right]_{\text {as. The GLODAP dataset }}{ }^{2}$ is used to calculate preindustrial ocean $\mathrm{CO}_{2}$ system variables. Following the established method of Broecker and Peng 3 , we account for DIC anomalies created by (1) freshwater addition or removal based on S, (2) soft-tissue carbon creation and respiration based on $\mathrm{PO}_{4}$, and (3) $\mathrm{CaCO}_{3}$ formation and dissolution based on ALK and nitrate $\left(\mathrm{NO}_{3}\right)$. See Fig. 1 for the simplified concept. We adopt the term $\mathrm{DIC}_{\text {as }}$ to represent net air-sea exchange component DIC signatures from:

$$
\begin{aligned}
\mathrm{DIC}_{\mathrm{as}}=\mathrm{DIC}_{\mathrm{s}}-\left(\mathrm{PO}_{4 \mathrm{~s}}\right. & \left.-\mathrm{PO}_{4}{ }^{\mathrm{mo}}\right) \times \mathrm{C} / \mathrm{PO}_{4} \\
& -1 / 2 \times\left(\mathrm{ALK}_{\mathrm{s}}-\mathrm{ALK}^{\mathrm{mo}}+\mathrm{NO}_{3 \mathrm{~s}}-\mathrm{NO}_{3}{ }^{\mathrm{mo}}\right)-\mathrm{DIC}_{\text {constant }}
\end{aligned}
$$

where the subscript " $\mathrm{s}$ " represents values normalized to $S$ of 35 (e.g., $\mathrm{DIC}_{\mathrm{s}}=\mathrm{DIC} \times$ $35 / S)$; the superscript "mo" denotes mean ocean values at $S=35\left(\mathrm{PO}_{4}{ }^{\mathrm{mo}}=2.2\right.$ $\mu \mathrm{mol} / \mathrm{kg}, \mathrm{ALK}^{\mathrm{mo}}=2383 \mu \mathrm{mol} / \mathrm{kg}, \mathrm{DIC}^{\mathrm{mo}}=2267 \mu \mathrm{mol} / \mathrm{kg}$, and $\mathrm{NO}_{3}{ }^{\mathrm{mo}}=31 \mu \mathrm{mol} /$ $\mathrm{kg})^{29} ; \mathrm{C} / \mathrm{PO}_{4}$ represents the soft-tissue stoichiometric Redfield ratio; and the arbitrary DIC constant $(=2285 \mu \mathrm{mol} / \mathrm{kg})$ is designed to bring zero DIC $\mathrm{Das}_{\text {close }}$ to the $\mathrm{NADW}-\mathrm{AABW}$ boundary (Fig. 2). The term $\left(\mathrm{PO}_{4 \mathrm{~s}}-\mathrm{PO}_{4} \mathrm{mo}\right) \times \mathrm{C} / \mathrm{PO}_{4}$ corrects for DIC changes due to photosynthesis and soft-tissue degradation, and the term $1 / 2 \times$ $\left(\mathrm{ALK}_{\mathrm{s}}-\mathrm{ALK}^{\mathrm{mo}}+\mathrm{NO}_{3 \mathrm{~s}}-\mathrm{NO}_{3} \mathrm{mo}\right)$ accounts for DIC changes caused by $\mathrm{CaCO}_{3}$ formation and dissolution. To be consistent with previous work ${ }^{3,30}$, we used $\mathrm{C} /$ $\mathrm{PO}_{4}=127$ to calculate $\mathrm{DIC}$ as and $\left[\mathrm{CO}_{3}{ }^{2-}\right]_{\mathrm{as}}$ in Fig. 2. Using other $\mathrm{C} / \mathrm{PO}_{4}$ values ${ }^{10}$ does not significantly affect spatial $\mathrm{DIC}_{\mathrm{as}}$ and $\left[\mathrm{CO}_{3}{ }^{2-}\right]_{\text {as }}$ patterns (Supplementary Figs. 11 and 12). Neither are their patterns affected by using other $\mathrm{PO}_{4}-\mathrm{ALK}-\mathrm{NO}_{3}$ values to replace global mean values in Eq. (1) (Supplementary Figs. 13 and 14). Ideally, DIC constant would be the mean DIC value of an abiotic ocean (Fig. 1), but this value cannot be simply determined from modern observations. Because our interest lies in spatial DIC $\mathrm{Ds}_{\mathrm{as}}$ contrasts instead of absolute values, the choice of $\mathrm{DIC}_{\text {constant }}$ has no effect on our interpretation.

To obtain $\left[\mathrm{CO}_{3}{ }^{2-}\right]_{\mathrm{as}}$, we first calculate $\left[\mathrm{CO}_{3}{ }^{2-}\right]_{\mathrm{PO} 4-\mathrm{T}-\mathrm{S}-\mathrm{P}}$ using $\left(\mathrm{DIC}_{\mathrm{as}}+\right.$ $\mathrm{DIC}_{\text {constant }}$ ), $\mathrm{ALK}{ }^{\mathrm{mo}}$, and $\mathrm{PO}_{4}{ }^{\mathrm{mo}}$ at $T=3{ }^{\circ} \mathrm{C}, S=35$, and $\mathrm{P}=2500 \mathrm{dbar}$. $\left[\mathrm{CO}_{3}{ }^{2-}\right]_{\mathrm{as}}$ is then calculated by $\left[\mathrm{CO}_{3}{ }^{2-}\right]_{\text {as }}=\left[\mathrm{CO}_{3}{ }^{2-}\right]_{\mathrm{PO} 4-\mathrm{T}-\mathrm{S}-\mathrm{P}-}-\left[\mathrm{CO}_{3}{ }^{2-}\right]_{\text {constant }}$, where $\left[\mathrm{CO}_{3}{ }^{2-}\right]_{\text {constant }}\left(=78 \mu \mathrm{mol} / \mathrm{kg}\right.$, calculated using $\mathrm{DIC}_{\text {constant }}$ and $\left.\mathrm{ALK}^{\mathrm{mo}}\right)$ is designed to bring zero $\left[\mathrm{CO}_{3}{ }^{2-}\right]_{\text {as }}$ close to the NADW-AABW boundary. In essence, the $\left[\mathrm{CO}_{3}{ }^{2-}\right]_{\mathrm{as}}$ distribution reflects the variation of $\left[\mathrm{CO}_{3}{ }^{2-}\right]$ when normalized to the same $\mathrm{PO}_{4}-\mathrm{T}-\mathrm{S}-\mathrm{P}$ conditions.

$\mathbf{C O}_{\mathbf{2}}$ system sensitivities and calculation of $\left[\mathbf{C O}_{3}{ }^{2-}\right]_{\text {Norm }}$. Because the seawater $\mathrm{CO}_{2}$ system is nonlinear, there is currently no simple way to derive these sensitivities based on $\mathrm{CO}_{2}$ system equations ${ }^{16}$. We use GLODAP preindustrial data to calculate numerically $\left[\mathrm{CO}_{3}^{2-}\right]$ sensitivities to various physiochemical parameters. Use of LGM outputs from the LOVECLIM model ${ }^{58}$ yields comparable sensitivities. We first use hydrographic data, including T, S, P, DIC, ALK, $\mathrm{PO}_{4}$, and $\mathrm{SiO}_{3}$ to calculate $\left[\mathrm{CO}_{3}{ }^{2-}\right]$. We then change $S$ to $35 \%$ and other chemical concentrations proportionally. For example, ALK and DIC will change as follows:

$$
\begin{gathered}
\mathrm{ALK}_{\mathrm{s}=35}=\mathrm{ALK} \times 35 / \mathrm{S}, \text { and } \\
\mathrm{DIC}_{\mathrm{s}=35}=\mathrm{DIC} \times 35 / \mathrm{S} .
\end{gathered}
$$

We use $S=35 \%$, $\mathrm{ALK}_{\mathrm{S}=35}, \mathrm{DIC}_{\mathrm{S}=35},\left[\mathrm{PO}_{4}\right]_{\mathrm{S}=35}$, and $\left[\mathrm{SiO}_{3}\right]_{\mathrm{S}=35}$ along with hydrographic $\mathrm{T}$ and $\mathrm{P}$ to calculate $\left[\mathrm{CO}_{3}{ }^{2-}\right]_{\mathrm{S}=35}$. The $\left[\mathrm{CO}_{3}{ }^{2-}\right]$ to $\mathrm{S}$ sensitivity (Sen_s) is calculated by:

$$
\operatorname{Sen}_{-S}=\left(\left[\mathrm{CO}_{3}^{2-}\right]-\left[\mathrm{CO}_{3}{ }^{2-}\right]_{\mathrm{S}=35}\right) /(\mathrm{S}-35) .
$$

To estimate temperature effects, we calculate $\left[\mathrm{CO}_{3}{ }^{2-}\right]_{\mathrm{S}=35}, \mathrm{~T}=3{ }^{\circ} \mathrm{C}$ using $S=35 \%$, $\mathrm{ALK}_{\mathrm{S}=35}, \mathrm{DIC}_{\mathrm{S}=35},\left[\mathrm{PO}_{4}\right]_{\mathrm{S}=35},\left[\mathrm{SiO}_{3}\right]_{\mathrm{S}=35}, T=3{ }^{\circ} \mathrm{C}$, and hydrographic $\mathrm{P}$. The sensitivity of $\left[\mathrm{CO}_{3}{ }^{2-}\right]_{\mathrm{S}=35}$ to temperature $\left(\mathrm{Sen}_{-} \mathrm{T}\right)$ is defined by:

$$
\mathrm{Sen}_{-\mathrm{T}}=\left(\left[\mathrm{CO}_{3}{ }^{2-}\right]_{\mathrm{S}=35, \mathrm{~T}=3^{\circ} \mathrm{C}}-\left[\mathrm{CO}_{3}{ }^{2-}\right]_{\mathrm{S}=35}\right) /(3-T) .
$$

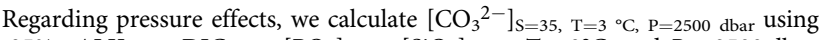
$S=35 \%, \mathrm{ALK}_{\mathrm{S}=35}, \mathrm{DIC}_{\mathrm{S}=35},\left[\mathrm{PO}_{4}\right]_{\mathrm{S}=35},\left[\mathrm{SiO}_{3}\right]_{\mathrm{S}=35}, \mathrm{~T}=3^{\circ} \mathrm{C}$, and $P=2500 \mathrm{dbar}$. The sensitivity of $\left[\mathrm{CO}_{3}{ }^{2-}\right]_{\mathrm{S}=35}, \mathrm{~T}=3^{\circ} \mathrm{C}$ to $\mathrm{P}\left(\mathrm{Sen}_{-} \mathrm{P}\right)$ is defined by:

$$
\begin{aligned}
\text { Sen }_{\perp}= & \left(\left[\mathrm{CO}_{3}{ }^{2-}\right]_{\mathrm{S}=35, \mathrm{~T}=3^{\circ} \mathrm{C}, \mathrm{P}=2500 \mathrm{dbar}}\right. \\
& \left.-\left[\mathrm{CO}_{3}{ }^{2-}\right]_{\mathrm{S}=35, \mathrm{~T}=3^{\circ} \mathrm{C}}\right) /(2500-P) \times 100 .
\end{aligned}
$$

To estimate the influence on $\left[\mathrm{CO}_{3}{ }^{2-}\right]$ from within-ocean ALK-DIC redistributions by biological processes, we assume a $0.1 \mu \mathrm{mol} / \mathrm{kg}$ increase in $\mathrm{PO}_{4}$ (i.e., $\Delta \mathrm{PO}_{4}=0.1 \mu \mathrm{mol} / \mathrm{kg}$ ) due to biological respiration (photosynthesis has an opposite effect). The resultant $\mathrm{ALK}\left(\mathrm{ALK}_{\mathrm{S}=35+\text { respiration }}\right)$ and $\mathrm{DIC}\left(\mathrm{DIC}_{\mathrm{S}=35+\text { respiration }}\right)$ can then be calculated from:

$$
\begin{aligned}
\mathrm{ALK}_{\mathrm{S}=35+\text { respiration }}= & \mathrm{ALK}_{\mathrm{s}=35}+\Delta \mathrm{PO}_{4} \times \mathrm{C} / \mathrm{PO}_{4} \\
& \div R \times 2-\Delta \mathrm{PO}_{4} \times \mathrm{N} / \mathrm{PO}_{4} .
\end{aligned}
$$

$$
\mathrm{DIC}_{\mathrm{S}=35+\text { respiration }}=\mathrm{DIC}_{\mathrm{s}=35}+\Delta \mathrm{PO}_{4} \times \mathrm{C} / \mathrm{PO}_{4}+\Delta \mathrm{PO}_{4} \times \mathrm{C} / \mathrm{PO}_{4} \div R .
$$

Resultant $\left[\mathrm{CO}_{3}{ }^{2-}\right]\left(\left[\mathrm{CO}_{3}{ }^{2-}\right]_{\mathrm{Norm}+\text { respiration }}\right)$ values are calculated using $\mathrm{DIC}_{\mathrm{S}=35+\text { respiration, }}, \mathrm{ALK}_{\mathrm{S}=35+\text { respiration, and }}\left(\left[\mathrm{PO}_{4}\right]_{\mathrm{S}=35}+\Delta \mathrm{PO}_{4}\right)$ at constant physical conditions of $T=3{ }^{\circ} \mathrm{C}, S=35$, and $P=2500 \mathrm{dbar}$. The sensitivity of 
$\left[\mathrm{CO}_{3}{ }^{2-}\right]_{\mathrm{Norm}}$ to $\mathrm{PO}_{4}$ is defined by:

$$
\begin{aligned}
& {\left[\mathrm{CO}_{3}{ }^{2-}\right]_{\mathrm{Norm}} / \mathrm{PO}_{4} \text { sensitivity }=} \\
& \left(\left[\mathrm{CO}_{3}{ }^{2-}\right]_{\text {Norm+respiration }}-\left[\mathrm{CO}_{3}{ }^{2-}\right]_{\mathrm{Norm}}\right) / \Delta \mathrm{PO}_{4} .
\end{aligned}
$$

We consider four Redfield stoichiometric scenarios: $\mathrm{C} / \mathrm{PO}_{4}=127, R=4$ (the reference composition; Fig. 4 d); $\mathrm{C} / \mathrm{PO}_{4}=140, R=4 ; \mathrm{C} \mathrm{PO}_{4}=127, R=8$; and $\mathrm{C} /$ $\mathrm{PO}_{4}=140, R=8$ (Supplementary Fig. 15). In all cases, strong exponential correlations exist between $\left[\mathrm{CO}_{3}{ }^{2-}\right]_{\mathrm{Norm}} / \mathrm{PO}_{4}$ sensitivities and $\left[\mathrm{CO}_{3}{ }^{2-}\right]_{\mathrm{Norm}}$. The correlations may reflect the buffering effect of the seawater $\mathrm{CO}_{2}$ system: for seawater with high DIC (low $\left[\mathrm{CO}_{3}{ }^{2-}\right]$ and high buffering capability), $\left[\mathrm{CO}_{3}{ }^{2-}\right]$ would be relatively less sensitive to biological DIC and ALK disturbances. All of the above sensitivity calculations assume no net air-sea $\mathrm{CO}_{2}$ change.

To calculate air-sea exchange sensitivities, we assume a $10 \mu \mathrm{mol} / \mathrm{kg}$ increase in $\mathrm{DIC}_{\mathrm{S}=35}$ due to atmospheric $\mathrm{CO}_{2}$ invasion (i.e., $\Delta \mathrm{DIC}_{\mathrm{as}}=10 \mu \mathrm{mol} / \mathrm{kg}$ ). We calculate $\left[\mathrm{CO}_{3}{ }^{2-}\right]_{\mathrm{Norm}+\text { as }}$ using $S=35 \%, \mathrm{ALK}_{\mathrm{S}=35}, \mathrm{DIC}_{\mathrm{S}=35+\text { as }}\left(=\mathrm{DIC}_{\mathrm{S}=35}+\right.$ $\left.\Delta \mathrm{DIC}_{\text {as }}\right),\left[\mathrm{PO}_{4}\right]_{\mathrm{S}=35},\left[\mathrm{SiO}_{3}\right]_{\mathrm{S}=35}, T=3^{\circ} \mathrm{C}$, and $P=2500 \mathrm{dbar}$. The sensitivity of $\left[\mathrm{CO}_{3}{ }^{2-}\right]_{\text {as }}$ to $\mathrm{DIC}_{\mathrm{as}}$ is defined by:

$$
\begin{aligned}
& {\left[\mathrm{CO}_{3}{ }^{2-}\right]_{\text {as }} / \mathrm{DIC}_{\text {as }} \text { sensitivity }=} \\
& \left(\left[\mathrm{CO}_{3}{ }^{2-}\right]_{\text {Norm +as }}-\left[\mathrm{CO}_{3}{ }^{2-}\right]_{\text {Norm }}\right) / \Delta \mathrm{DIC}_{\text {as }} .
\end{aligned}
$$

Using sensitivities shown in Fig. $4,\left[\mathrm{CO}_{3}{ }^{2-}\right]_{\text {Norm }}$ can be calculated by:

$$
\begin{aligned}
{\left[\mathrm{CO}_{3}{ }^{2-}\right]_{\text {Norm }}=} & {\left[\mathrm{CO}_{3}{ }^{2-}\right]+(35-S) \times \operatorname{Sen}_{-}+(3-T) } \\
& \times \operatorname{Sen}_{-\mathrm{T}}+(2500-P) / 100 \times \operatorname{Sen}_{-\mathrm{P}} .
\end{aligned}
$$

Excel spreadsheets are provided in Supplementary Data 7-8 to calculate $\left[\mathrm{CO}_{3}{ }^{2-}\right]_{\text {Norm }}$ and the biological curves shown in Fig. 5 .

LGM-Holocene North Atlantic carbon budget. The total extra carbon increase $\left(\Delta \Sigma \mathrm{C}_{\mathrm{LGM}-\text { Holocene }}\right)$ in Fig. 6 is calculated by $\Delta \Sigma \mathrm{C}_{\mathrm{LGM}-\text { Holocene }}=V \times$ density $\times$ $\%$ GNAIW $\times\left(\left[\mathrm{CO}_{3}{ }^{2-}\right]_{\text {as }}\right.$ oDP999-BOFS $\left.{ }^{\mathrm{LGM}} / 0.61\right) \times 12-V \times$ density $\times \%$ NADW $\times$ $\left(\left[\mathrm{CO}_{3}{ }^{2-}\right]_{\text {as_oDp999-BOFS }}\right.$ Holocene/0.59) $\times 12$, where $V$ is the global deep ocean volume ( $>1 \mathrm{~km}$ water depth) at $100.8 \times 10^{16} \mathrm{~m}^{3}$, density $=1027.8 \mathrm{~kg} / \mathrm{m}^{3}$ (ref. $\left.{ }^{29}\right)$, $\%$ GNAIW and \%NADW, respectively, represent their volume fractions in the deep ocean, $\left[\mathrm{CO}_{3}{ }^{2-}\right]_{\text {as_ODP999-BOFS }}{ }^{\text {Holocene }}=56 \mu \mathrm{mol} / \mathrm{kg},\left[\mathrm{CO}_{3}{ }^{2-}\right]_{\text {as_oDP999-BOFS }}{ }^{\mathrm{LGM}}=$ $114 \mu \mathrm{mol} / \mathrm{kg}$ (Fig. 5), terms 0.61 and 0.58 , respectively, represent the absolute LGM and Holocene $\left[\mathrm{CO}_{3}{ }^{2-}\right]_{\text {as }} / \mathrm{DIC}_{\mathrm{as}}$ sensitivities (Fig. 4e) used to transfer $\left[\mathrm{CO}_{3}{ }^{2-}\right]_{\text {as_oDP999-BOFs }}$ into ODP999-BOFS DIC ${ }_{\text {as }}$ contrasts (LGM: $186 \mu \mathrm{mol} / \mathrm{kg}$; Holocene: $95 \mu \mathrm{mol} / \mathrm{kg}$ ), and the number 12 converts $C$ from moles into weight. Based on previous estimates, \%NADW is thought to be $\sim 50 \%$ (refs. ${ }^{38,39}$ ), while $\%$ GNAIW remained roughly similar to \%NADW or shrank (refs. ${ }^{35,36}$ ). These estimates are debated and have large uncertainties, and we thus calculate $\Delta \Sigma \mathrm{C}_{\mathrm{LGM}-\mathrm{Holocene}}$ for a range of \%NADW and \%GNAIW values (Fig. 6). Any influence from AAIW is ignored because of its similar $\left[\mathrm{CO}_{3}{ }^{2-}\right]_{\text {as }}$ signals to Gulf Stream during the Holocene (Supplementary Fig. 3) and much reduced northward advection during the $\mathrm{LGM}^{23,31-33}$. We tentatively treat $\Delta \Sigma \mathrm{C}_{\mathrm{LGM} \text {-Holocene }}$ of $\sim 100$ PgC using $\% \mathrm{NADW}=50 \%$ and $\% \mathrm{GNAIW}=30 \%$ as our best estimate. Assuming no Holocene-LGM DIC as gradient change (i.e., the same $\mathrm{CO}_{2}$ uptake efficiency) and everything else being equal, $\Delta \Sigma \mathrm{C}_{\mathrm{LGM}-\mathrm{Holocene}}$ would be $-240 \mathrm{PgC}$ at $\% \mathrm{NADW}=50 \%$ and $\% \mathrm{GNAIW}=30 \%$.

Cores, age models, samples, and analytical methods. We used ODP Site 999 for Gulf Stream surface-water reconstructions (Fig. 2). The age model is from Schmidt et al. ${ }^{59}$. Planktonic foraminiferal Globigerinoides ruber (sensu stricto, white variety) $\delta^{18} \mathrm{O}, \mathrm{Mg} / \mathrm{Ca}$, and $\delta^{11} \mathrm{~B}$ data are from refs. ${ }^{21,22,59}$. Briefly, about 25 and 55 shells from the $250-350 \mu \mathrm{m}$ size fraction were used for $\delta^{18} \mathrm{O}$ and $\mathrm{Mg} / \mathrm{Ca}$ analyses, respectively. Samples for $\delta^{18} \mathrm{O}$ analyses were sonicated in methanol for $5-10 \mathrm{~s}$, roasted under vacuum at $375^{\circ} \mathrm{C}$ for $30 \mathrm{~min}$, and analyzed on a Fisons Optima IRMS with a precision of $<0.06 \%$. Shells for $\mathrm{Mg} / \mathrm{Ca}$ were cleaned following the reductive cleaning procedure ${ }^{60}$ and measured on an inductively-coupled plasma mass spectrometer (ICP-MS) with a precision of $\sim 1.7 \%$. For $\delta^{11} \mathrm{~B}$ analyses, about $100-120$ G. ruber $(\mathrm{w})$ shells from the $300-355 \mu \mathrm{m}$ size fraction were cleaned following the "Mg-cleaning" procedure ${ }^{61}$, to minimize material loss during cleaning $^{62}$. G. ruber (w) $\delta^{11} \mathrm{~B}$ was measured on a Neptune multicollector (MC)-ICP-MS with an analytical error in $\delta^{11} \mathrm{~B}$ of about $\pm 0.25 \%$ (ref. ${ }^{21}$ ).

Three cores (BOFS 17, BOFS 11, and BOFS $14 \mathrm{~K}$ ) from the polar North Atlantic Ocean are used for deep-water reconstructions (Fig. 3). Their age models are based on published chronologies ${ }^{24,63-65}$. For each sample ( $\sim 2 \mathrm{~cm}$ thickness), $\sim 10-20 \mathrm{~cm}^{3}$ of sediment was disaggregated in de-ionized water and was wet sieved through 63 $\mu \mathrm{m}$ sieves. To facilitate analyses, we picked the most abundant species for measurements. For each B/Ca analysis, 10-20 monospecific shells of the benthic foraminifera C. mundulus (BOFS $17 \mathrm{~K}$ ) and C. wuellerstorfi (BOFS 14, $11 \mathrm{~K}$ ) were obtained from 250 to $500 \mu \mathrm{m}$ size fraction. The shells were double checked under a microscope before crushing to ensure that consistent morphologies were used throughout the core. On average, following this careful screening the starting material for each sample was $\sim 8-12$ shells, which is equivalent to $\sim 300-600 \mu \mathrm{g}$ of carbonate. For benthic B/Ca analyses, foraminiferal shells were cleaned with either the "Mg-cleaning" method ${ }^{61}$ or the "Cd-cleaning" protocol ${ }^{61}$, to investigate cleaning effects on trace element/Ca in foraminiferal shells ${ }^{62,66}$. No discernable B/ $\mathrm{Ca}$ difference is observed between the two cleaning methods ${ }^{25,62}$. Benthic B/Ca ratios were measured on an ICP-MS using procedures outlined in ref. ${ }^{67}$, with an analytical error better than $\sim 5 \%$.

For each benthic $\mathrm{Cd} / \mathrm{Ca}$ analysis, $\sim 10-20$ shells of the benthic foraminiferal taxa C. mundulus (BOFS $17 \mathrm{~K}$ ), C. wuellerstorfi (BOFS $14 \mathrm{~K}, 11 \mathrm{~K}$ ), and Uvigerina spp. (BOFS $17 \mathrm{~K}$ ) were picked from the $250-500 \mu \mathrm{m}$ size fraction. Previous studies ${ }^{26,27,68}$ showed similar $\mathrm{Cd} / \mathrm{Ca}$ ratios between infaunal Uvigerina spp. and epifaunal Cibicidoides, and we thus combined $\mathrm{Cd} / \mathrm{Ca}$ data from these taxa to obtain continuous downcore $\mathrm{PO}_{4}$ records. We used the "Cd-cleaning" method ${ }^{60,69}$ to clean benthic shells for $\mathrm{Cd} / \mathrm{Ca}$ measurements. $\mathrm{Cd} / \mathrm{Ca}$ ratios were measured on an ICP-MS with an analytical error better than $\sim 5 \%$ (ref. ${ }^{67}$ )

For $\delta^{11} \mathrm{~B}$ measurements, about 20 benthic shells from the $250-500 \mu \mathrm{m}$ size fraction were picked for each sample. Shells used for $\delta^{11} \mathrm{~B}$ analyses were cleaned using the "Mg-cleaning" method, to minimize loss of shell material ${ }^{61}$. After cleaning, shells were dissolved and pure boron was extracted using column chemistry as described by Foster ${ }^{21}$. Benthic $\delta^{11} \mathrm{~B}$ was measured on a Neptune multi-collector (MC)-ICP-MS following ref. ${ }^{21}$. The analytical error in $\delta^{11} \mathrm{~B}$ is about $\pm 0.25 \%$. Due to the relatively large sample size requirement, shell availability, and lengthy chemical treatments for $\delta^{11} \mathrm{~B}$, we present low-resolution $\delta^{11} \mathrm{~B}$ for C. mundulus from BOFS $17 \mathrm{~K}$ and for C. wuellerstorfi from BOFS $11 \mathrm{~K}$. Note that consistent $\left[\mathrm{CO}_{3}{ }^{2-}\right]$ results from $\mathrm{B} / \mathrm{Ca}$ and $\delta^{11} \mathrm{~B}$ strengthen the reliability of our reconstructions (Fig. 3).

Published benthic $\mathrm{Cd} / \mathrm{Ca}$ and $\mathrm{B} / \mathrm{Ca}$ results are included in Fig. 3. Altogether, we generated 180 new measurements of benthic $\delta^{11} \mathrm{~B}, \mathrm{~B} / \mathrm{Ca}$, and $\mathrm{Cd} / \mathrm{Ca}$. All data are listed in Supplementary Data 1-9.

ODP 999 reconstructions. ODP Site 999 was used to constrain past physical conditions and carbonate chemistry of the Gulf Stream (Supplementary Fig. 4). Following previous approaches ${ }^{21,22}$, surface water temperature $\left(\mathrm{T}_{\text {surface }}\right)$ and salinity $\left(\mathrm{S}_{\text {surface }}\right)$ were estimated based on $\mathrm{G}$. ruber $\mathrm{Mg} / \mathrm{Ca}$ (ref. ${ }^{59}$ ) and sea level changes ${ }^{21,22,59}$, respectively. We first convert G. ruber $\delta^{11} \mathrm{~B}$ to borate $\delta^{11} \mathrm{~B}$ $\left(\delta^{11} \mathrm{~B}_{\text {borate }}\right)$, following the conversion method of ref. ${ }^{22}$. Surface water $\mathrm{pH}\left(\mathrm{pH}_{\text {surface }}\right)$ was calculated from seawater $\delta^{11} \mathrm{~B}_{\text {borate }}$ along with $\mathrm{T}_{\text {surface }}$ and $\mathrm{S}_{\text {surface. }}$. To constrain the $\mathrm{CO}_{2}$ system, two $\mathrm{CO}_{2}$ system variables are necessary ${ }^{16}$. In addition to $\delta^{11} \mathrm{~B}$ derived $\mathrm{pH}$, literature studies ${ }^{21,22,41}$ generally estimate past surface-water ALK $\left(\mathrm{ALK}_{\text {surface }}\right)$ changes. Following refs. ${ }^{21,22}$, we estimate $\mathrm{ALK}_{\text {surface }}$ from $\mathrm{S}_{\text {surface }}$ using the modern $\mathrm{S}_{\text {surface }}-\mathrm{ALK}_{\text {surface }}$ relationship $\left(\mathrm{ALK}_{\text {surface }}=59.19 \times \mathrm{S}_{\text {surface }}+229.08\right.$, $\left.R^{2}=0.99\right)^{21}$. Together with $\mathrm{T}_{\text {surface }}$ and $\mathrm{S}_{\text {surface, }} \mathrm{pH}_{\text {surface }}$, and $\mathrm{ALK}_{\text {surface }}$ were used to calculate other $\mathrm{CO}_{2}$ system variables including surface-water $\left[\mathrm{CO}_{3}{ }^{2-}\right]$ $\left(\left[\mathrm{CO}_{3}{ }^{2-}\right]_{\text {surface }}\right)$ and DIC (DIC surface $)$ using the $\mathrm{CO}_{2}$ sys program ${ }^{28}$. Surface-water $\mathrm{PO}_{4}$ concentration at ODP 999 is assumed to be zero over the last $27 \mathrm{ka}$.

Following refs. ${ }^{21,22,59}$, errors are estimated to be $1{ }^{\circ} \mathrm{C}, 1 \%, 100 \mu \mathrm{mol} / \mathrm{kg}$, and $\sim 0.43 \%$ for $\mathrm{T}_{\text {surface, }} \mathrm{S}_{\text {surface, }}, \mathrm{ALK}_{\text {surface, }}$ and $\delta^{11} \mathrm{~B}_{\text {borate }}$, respectively. Integrated average uncertainties in $\left[\mathrm{CO}_{3}{ }^{2-}\right]_{\text {surface }}$ and $\mathrm{DIC}_{\text {surface }}$ for a single reconstruction are, respectively, $\sim 20$ (Holocene: $\sim 18$, LGM: $\sim 24$ ) and $\sim 90 \mu \mathrm{mol} / \mathrm{kg}$, based on quadratic addition of all individual errors sourced from $\mathrm{T}_{\text {surface }}\left(\left[\mathrm{CO}_{3}{ }^{2-}\right]_{\text {surface }}: 2 \mu \mathrm{mol} / \mathrm{kg}\right.$, $\left.\mathrm{DIC}_{\text {surface: }}: 3 \mu \mathrm{mol} / \mathrm{kg}\right), \mathrm{S}_{\text {surface }}\left(\left[\mathrm{CO}_{3}{ }^{2-}\right]_{\text {surface }}: 2 \mu \mathrm{mol} / \mathrm{kg}\right.$, DIC surface: $\left.5 \mu \mathrm{mol} / \mathrm{kg}\right)$, ALK $_{\text {surface }}\left(\left[\mathrm{CO}_{3}{ }^{2-}\right]_{\text {surface: }} 14 \mu \mathrm{mol} / \mathrm{kg}\right.$, DIC surface: $\left.^{2} 6 \mu \mathrm{mol} / \mathrm{kg}\right)$, and $\delta^{11} \mathrm{~B}_{\text {borate }}$ ( $\left[\mathrm{CO}_{3}{ }^{2-}\right]_{\text {surface: }} 16 \mu \mathrm{mol} / \mathrm{kg}$, DIC $\mathrm{C}_{\text {surface: }} 24 \mu \mathrm{mol} / \mathrm{kg}$; note that $\delta^{11} \mathrm{~B}_{\text {borate }}$ leads to an error in $\left[\mathrm{CO}_{3}{ }^{2-}\right]$ via $\left.\mathrm{pH}\right)$. Uncertainties for calculated $\mathrm{CO}_{2}$ system variables at ODP 999 are tabulated in Supplementary Data 1. Use of other methods to estimate ALK would have little impact on our conclusions (Supplementary Figs. 16 and 17).

From $\mathbf{p H}$ to $\left[\mathrm{CO}_{3}{ }^{2-}\right]$. For palaeo-studies, surface-water $\mathrm{pH}$ is generally obtained from planktonic foraminiferal $\delta^{11} \mathrm{~B}$. To calculate $\left[\mathrm{CO}_{3}{ }^{2-}\right.$, a second $\mathrm{CO}_{2}$ system variable is needed ${ }^{16}$. Following the previous approach ${ }^{21,22}$, past $\mathrm{ALK}_{\text {surface }}$ at ODP 999 have been estimated from $\mathrm{S}$ using the $\mathrm{S}_{\text {surface }}-\mathrm{ALK}_{\text {surface }}$ relationship. Due to limited knowledge about the past $\mathrm{S}_{\text {surface }}-\mathrm{ALK}_{\text {surface }}$ relationship, a generous uncertainty has been assigned to $\mathrm{ALK}_{\text {surface }}$ at $\pm 100 \mu \mathrm{mol} / \mathrm{kg}$ (ref. ${ }^{21,22}$ ), which is about half of the entire ALK range in the present global ocean ${ }^{2}$. Using $\mathrm{ALK}_{\text {surface }}$ and $\mathrm{pH}_{\text {surface }}$ along with $\mathrm{T}_{\text {surface }}$ and $\mathrm{S}_{\text {surface, }}\left[\mathrm{CO}_{3}{ }^{2-}\right]_{\text {surface }}$ and DIC $\mathrm{Durface}_{\text {can be }}$ calculated using the $\mathrm{CO}_{2}$ sys program ${ }^{28}$. Because of the large uncertainty in

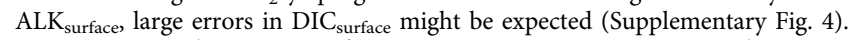
However, given the constraint from $\mathrm{pH}_{\text {surface }}$, seawater $\mathrm{ALK}_{\text {surface }}$ and DIC $\mathrm{Durface}_{\text {suce }}$ variations are not random but must vary systematically within ALK-DIC space (Supplementary Fig. 5). Because of the close relationship between $\mathrm{pH}$ and $\left[\mathrm{CO}_{3}{ }^{2-}\right]$ (i.e., roughly parallel patterns of $\mathrm{pH}$ and $\left[\mathrm{CO}_{3}{ }^{2-}\right]$ within ALK-DIC space; Supplementary Fig. 5), this systematic ALK-DIC variation allows us to confine $\left[\mathrm{CO}_{3}{ }^{2-}\right]$ with acceptable uncertainty. For a given $\mathrm{pH}$ at ODP 999, an error of 100 $\mu \mathrm{mol} / \mathrm{kg}$ in ALK only leads to an error of about $\pm 14 \mu \mathrm{mol} / \mathrm{kg}$ in $\left[\mathrm{CO}_{3}{ }^{2-}\right.$ ] (Supplementary Fig. 5).

For clarity, Supplementary Fig. 5a, b only consider the effect of ALK errors on $\left[\mathrm{CO}_{3}{ }^{2-}\right]$ estimates assuming constant $\mathrm{pH}$ and T-S-P conditions. To fully propagate errors from various sources including $\mathrm{T}_{\text {surface }} \mathrm{S}_{\text {surface }}, \mathrm{ALK}_{\text {surface, }}$ and $\mathrm{pH}_{\text {surface, }}$ we use a Monte Carlo approach $(n=10,000)$ to calculate the integrated error in $\left[\mathrm{CO}_{3}{ }^{2-}\right]$ $\left(\right.$ ref. $\left.{ }^{70}\right)$. As can be seen from Supplementary Fig. $5 \mathrm{c}-\mathrm{f}$, the final errors $(\sim 20-25 \mu \mathrm{mol} /$ $\mathrm{kg})$ in an individual $\left[\mathrm{CO}_{3}{ }^{2-}\right]$ reconstruction based on the Monte-Carlo are similar to those $(\sim 18-24 \mu \mathrm{mol} / \mathrm{kg})$ based on quadratic addition of individual errors, justifying our major error estimation approach (i.e., quadratic addition). 
Subtropical western North Atlantic surface $\left[\mathrm{CO}_{3}{ }^{2-}\right]$. Because most of North Atlantic subtropical gyre waters circulate through the Caribbean Sea before being transported to the subpolar North Atlantic via the Gulf Stream, ODP 999 from Caribbean Sea is used to constrain past Gulf Stream carbonate chemistry ${ }^{20}$. To further test the feasibility of using ODP 999 to represent the first-order Gulf Stream $\left[\mathrm{CO}_{3}{ }^{2-}\right]$ changes during the Holocene and LGM, we have estimated surface-water $\left[\mathrm{CO}_{3}{ }^{2-}\right]$ for four sites from the wider subtropical western Atlantic region (latitude: $12-33^{\circ} \mathrm{N}$, longitude: $\left.61-91^{\circ} \mathrm{W}\right)$. Among these sites, KNR140-51GGC $\left(33^{\circ} \mathrm{N}, 76^{\circ} \mathrm{W}\right)$ is located within the Gulf Stream today ${ }^{71}$. Because subtropical surface waters cycle multiple times through the upper ocean gyre circulations, it is possible that surface waters have been close to equilibrium with past atmospheric $p \mathrm{CO}_{2}$ (refs. ${ }^{21,22}$ ). Therefore, we assume surface-water $p \mathrm{CO}_{2}$ of 270 and $194 \mathrm{ppm}$ for the Holocene and LGM, respectively ${ }^{72}$. We assign a $\pm 15 \mathrm{ppm}$ error to surface-water $p \mathrm{CO}_{2}$ to account for any potential air-sea $\mathrm{CO}_{2}$ disequilibrium. For these sites, we use surface temperature and salinity reconstructions from previous publications ${ }^{71,73-75}$. ALK is calculated based on the same approach for ODP 999. The reconstructed in situ $\left[\mathrm{CO}_{3}{ }^{2-}\right]$ values show some differences between cores, due to local T-S conditions. Since we are interested in air-sea $\mathrm{CO}_{2}$ exchange signals, we convert reconstructed in situ $\left[\mathrm{CO}_{3}{ }^{2-}\right]$ into $\left[\mathrm{CO}_{3}{ }^{2-}\right]_{\text {Norm }}$ using Eq. (11). As can be seen from Supplementary Fig. 6 and Supplementary Data 2, these cores show similar $\left[\mathrm{CO}_{3}{ }^{2-}\right]_{\mathrm{Nor}}$ values for the Holocene $(\sim 260 \mu \mathrm{mol} / \mathrm{kg})$ and LGM $(\sim 300 \mu \mathrm{mol} / \mathrm{kg})$ as ODP 999 . Therefore, we argue that ODP 999 sufficiently records first-order Gulf Stream air-sea exchange carbonate chemistry for the Holocene and LGM. Because we aim to obtain a proxy-based estimates, we use ODP 999 data for calculations in the main text.

Benthic $\mathbf{B} / \mathrm{Ca}$ and $\boldsymbol{\delta}^{11} \mathbf{B}$ to deep-water $\left[\mathrm{CO}_{3}{ }^{2-}\right]$. Most deep-water $\left[\mathrm{CO}_{3}{ }^{2-}\right]$ values are reconstructed using benthic $\mathrm{B} / \mathrm{Ca}\left(\right.$ refs. $\left.{ }^{25,47}\right)$ from $\left[\mathrm{CO}_{3}{ }^{2-}\right]_{\text {downcore }}=\left[\mathrm{CO}_{3}{ }^{2-}\right]_{\mathrm{PI}}+$ $\Delta \mathrm{B} / \mathrm{Ca}_{\text {downcore-coretop }} / k$, where $\left[\mathrm{CO}_{3}{ }^{2-}\right]_{\mathrm{PI}}$ is the preindustrial (PI) deep-water $\left[\mathrm{CO}_{3}{ }^{2-}\right]$ value estimated from the GLODAP dataset ${ }^{2}, \Delta \mathrm{B} / \mathrm{Ca}_{\text {downcore-coretop }}$ represents the deviation of $\mathrm{B} / \mathrm{Ca}$ of down-core samples from the core-top value, and $k$ is the $\mathrm{B} / \mathrm{Ca}-\left[\mathrm{CO}_{3}{ }^{2-}\right]$ sensitivity of $C$. wuellerstorf $(1.14 \mu \mathrm{mol} / \mathrm{mol} \mathrm{per} \mu \mathrm{mol} /$ $\mathrm{kg})$ or C. mundulus $(0.69 \mu \mathrm{mol} / \mathrm{mol} \mathrm{per} \mu \mathrm{mol} / \mathrm{kg})^{25}$. We use a reconstruction uncertainty of $\pm 10 \mu \mathrm{mol} / \mathrm{kg}$ in $\left[\mathrm{CO}_{3}{ }^{2-}\right]$ based on global core-top calibration samples ${ }^{25,76}$

For cores BOFS $17 \mathrm{~K}$ and BOFS $11 \mathrm{~K}$, new monospecific epifaunal benthic $\delta^{11} \mathrm{~B}$ values were converted into deep-water $\left[\mathrm{CO}_{3}{ }^{2-}\right]$ following the approach detailed in ref. ${ }^{77}$. Briefly, benthic $\delta^{11} \mathrm{~B}$ is assumed to directly reflect deep-water borate $\delta^{11} \mathrm{~B}$, as suggested by previous core-top calibration work ${ }^{78}$. Deep-water $\mathrm{pH}$ is calculated using benthic $\delta^{11} \mathrm{~B}$ along with $\mathrm{T}_{\text {deep }}$ and $\mathrm{S}_{\text {deep }}$, similar to the approach to calculate surface-water $\mathrm{pH}$ at ODP 999 (refs. ${ }^{21,22}$ ). We assume constant ALK at the studied sites $(2313 \mu \mathrm{mol} / \mathrm{kg}$ at BOFS $17 \mathrm{~K}$ and $2310 \mu \mathrm{mol} / \mathrm{kg}$ at BOFS $11 \mathrm{~K})$ in the past. Following ref. ${ }^{77}$, a generous error of $100 \mu \mathrm{mol} / \mathrm{kg}$ is assigned to ALK estimates. We then calculate deep-water $\left[\mathrm{CO}_{3}{ }^{2-}\right]$ from $\mathrm{pH}$ and ALK using the $\mathrm{CO}_{2}$ sys program ${ }^{28}$. The integrated average uncertainty in deep-water $\left[\mathrm{CO}_{3}{ }^{2-}\right]$ is $\pm 10 \mu \mathrm{mol} / \mathrm{kg}$, based on quadratic addition of individual errors of $\sim \pm 2 \mu \mathrm{mol} / \mathrm{kg}$ sourced from $\mathrm{T}_{\text {deep }}\left( \pm 1{ }^{\circ} \mathrm{C}\right), \sim \pm 2 \mu \mathrm{mol} / \mathrm{kg}$ from $\mathrm{S}_{\text {deep }}( \pm 1 \%$ ), $\sim \pm 5 \mu \mathrm{mol} / \mathrm{kg}$ from ALK $( \pm 100 \mu \mathrm{mol} / \mathrm{kg})$, and $\sim \pm 8 \mu \mathrm{mol} / \mathrm{kg}$ from $\delta^{11} \mathrm{~B}_{\text {borate }}(\sim \pm 0.25 \%)$. As demonstrated by Supplementary Fig. 5, the large ALK error only contributes a small uncertainty to the final $\left[\mathrm{CO}_{3}{ }^{2-}\right]$ estimate. As shown in Fig. 3, benthic $\mathrm{B} / \mathrm{Ca}$ and $\delta^{11} \mathrm{~B}$ yield consistent deep-water $\left[\mathrm{CO}_{3}{ }^{2-}\right]$ reconstructions for the Holocene and LGM.

Benthic $\mathbf{C d} / \mathbf{C a}$ to deep-water $\mathbf{P O}_{\mathbf{4}}$. We follow the established approach ${ }^{26,46,79}$ to convert benthic (C. wuellerstorfi, C. mundulus, and Uvigerina spp.) foraminiferal $\mathrm{Cd} / \mathrm{Ca}$ into deep-water $\mathrm{Cd}$ concentrations. Partition coefficients $\left(D_{\mathrm{Cd}}\right)$ are used to calculate deep water Cd from: $\mathrm{Cd}(\mathrm{nmol} / \mathrm{kg})=\left[(\mathrm{Cd} / \mathrm{Ca})_{\text {foram }} / D_{\mathrm{Cd}}\right] \times 10$. Bertram et al. ${ }^{65}$ used empirical $D_{\mathrm{Cd}}$ values of $2.3,2.2$, and 2.7 for BOFS 17,14 , and $11 \mathrm{~K}$ respectively. However, these $D_{\mathrm{Cd}}$ values would result in Holocene $\mathrm{Cd}$ of $0.3-0.4$ $\mathrm{nmol} / \mathrm{kg}$, higher than the observed value of $\sim 0.25 \mathrm{nmol} / \mathrm{kg}$ from modern hydrographic measurements (Supplementary Fig. 7) ${ }^{80}$. This offset may suggest higher $D_{\text {Cd }}$ values for the North Atlantic Ocean, which has been acknowledged recently ${ }^{81}$. We thus adjust $\mathrm{D}_{\mathrm{Cd}}(\sim 25 \%$ increase) so that the calculated Holocene deep-water $\mathrm{Cd}$ concentrations match modern measurements. This adjustment is supported by consistent $\mathrm{Cd}$ reconstructions from this study and previous reconstructions based on $\mathrm{Cd} / \mathrm{Ca}$ measurements for Hoeglundina elegans. Compared to Cibicidoides, $D_{\mathrm{Cd}}$ into H. elegans is far less variable ${ }^{79}$. As can be seen from Supplementary Fig. 8, for cores with similar benthic $\delta^{13} \mathrm{C}$ from similar water depths (i.e., bathed in similar water masses), our $\mathrm{Cd}$ reconstructions match favorably with those based on $H$. elegans measurements ${ }^{82}$. Deep water $\mathrm{Cd}$ is converted into $\mathrm{PO}_{4}$ using the relationship based on the latest North Atlantic Ocean measurements (Supplementary Fig. 7) ${ }^{80}$. Using older published $\mathrm{Cd}-\mathrm{PO}_{4}$ relationships ${ }^{26,83}$ only marginally affects our $\mathrm{PO}_{4}$ estimates.

Uncertainties associated with $\mathrm{Cd}$ and $\mathrm{PO}_{4}$ reconstructions are estimated as follows. Error for Cd is estimated using $2 \sigma_{\mathrm{Cd}}=\sqrt{\left(2 \sigma_{D_{\mathrm{Cd}}}\right)^{2}+\left(2 \sigma_{\mathrm{Cd} / \mathrm{Ca}}\right)^{2}}$, where $2 \sigma_{D_{\mathrm{Cd}}}$ and $2 \sigma_{\mathrm{Cd} / \mathrm{Ca}}(=5 \%)$ are errors for $D_{\mathrm{Cd}}$ and $\mathrm{Cd} / \mathrm{Ca}$, respectively. Due to poorly defined uncertainty for $D_{\mathrm{Cd}}$ from the literature, we assume an error of $50 \%$, and then compare our final errors with literature estimates to assess the appropriateness of our calculations. Seawater $\mathrm{PO}_{4}$ is calculated from Cd using: $\mathrm{PO}_{4}=\frac{\mathrm{Cd}-\mathrm{b} \pm\left(2 \sigma_{\mathrm{b}}\right)}{a \pm\left(2 \sigma_{b}\right)}$, where $2 \sigma_{a}$ and $2 \sigma_{b}$, respectively, represent $95 \%$ confidence errors associated with $a$ and $b$ (Supplementary Fig. $7 \mathrm{~b}$ ). The $\mathrm{PO}_{4}$ uncertainty was calculated from:

$2 \sigma_{\mathrm{PO}_{4}}=\sqrt{\left(\partial_{\mathrm{PO}_{4}} / \partial_{a} \cdot 2 \sigma_{a}\right)^{2}+\left(\partial_{\mathrm{PO}_{4}} / \partial_{b} \cdot 2 \sigma_{b}\right)^{2}+\left(\partial_{\mathrm{PO}_{4}} / \partial_{\mathrm{Cd}} \cdot 2 \sigma_{\mathrm{Cd}}\right)^{2}}$, where

$\partial_{\mathrm{PO}_{4}} / \partial_{a}=\frac{-(\mathrm{Cd}-\mathrm{b})}{a^{2}}, \partial_{\mathrm{PO}_{4}} / \partial_{b}=\frac{-1}{a}$, and $\partial_{\mathrm{PO}_{4}} / \partial_{\mathrm{Cd}}=\frac{1}{a}$. Our final errors on individual $\mathrm{Cd}$ and $\mathrm{PO}_{4}$ are $\sim 0.12 \mathrm{nmol} / \mathrm{kg}(\sim 55 \%)$ and $\sim 0.5 \mu \mathrm{mol} / \mathrm{kg}(\sim 50 \%)$, respectively. When compared with previously published uncertainties $(\sim 0.08 \mathrm{nmol} / \mathrm{kg}$ for Cd and $\sim 0.17 \mu \mathrm{mol} / \mathrm{kg}$ for $\left.\mathrm{PO}_{4}\right)^{46,68}$, our error estimates are possibly too generous. Here we use $\sim 50 \%$ error to be conservative. We encourage future work to improve uncertainty estimates for the benthic $\mathrm{Cd} / \mathrm{Ca}$ proxy.

The oceanic residence time of $\mathrm{PO}_{4}$ is $\sim 100,000$ years ${ }^{84}$. The LGM deep ocean was possibly more reducing ${ }^{85}$, which might have facilitated sediment organic matter preservation, and, thus, $\mathrm{PO}_{4}$ removal from the ocean. However, this effect might have been compensated by decreased organic burial on continental slopes due to shallower LGM sea levels ${ }^{86,87}$. Considering the short ( $\sim 10,000$ years) last deglacial ${ }^{84}$, we assume that global $\mathrm{PO}_{4}$ and $\mathrm{Cd}$ reservoirs remained constant between the Holocene and LGM. Our reconstructions (Fig. 3) are consistent with high benthic $\delta^{13} \mathrm{C}$ and low benthic $\mathrm{Cd} / \mathrm{Ca}$ at numerous glacial North Atlantic middepth sites $23,31,46,65,88,89$.

Deep-water temperature and salinity estimates. Deep-water temperature $\left(\mathrm{T}_{\text {deep }}\right)$ is estimated from the ice volume corrected benthic $\delta^{18} \mathrm{O}\left(\delta^{18} \mathrm{O}_{\mathrm{IVC}}\right)$ and the $\delta^{18} \mathrm{O}$ temperature equation of Marchitto et al. ${ }^{90}$ from $T_{\text {deep }}=2.5-\left(\delta^{18} \mathrm{O}_{\text {IVC }}-2.8\right) / 0.224$, where $\delta^{18} \mathrm{O}_{\text {IVC }}=\delta^{18} \mathrm{O}_{\text {benthic }}-\delta_{18} \mathrm{O}_{\text {global sealevel. }} \delta^{18} \mathrm{O}_{\text {global sealevel was estimated from }}$ sea level curves ${ }^{86,87}$ with a global $\delta^{18} \mathrm{O}_{\text {seawater }}-$ sea level scaling of $0.0085 \% / \mathrm{m}\left(\right.$ ref. $\left.{ }^{91}\right)$. Deep-water salinity $\left(\mathrm{S}_{\text {deep }}\right)$ is calculated by: $S_{\text {deep }}=S_{\text {core_top }}+1.11 \times \delta^{18} \mathrm{O}_{\text {global_sealevel }}$, where $S_{\text {core top }}$ is the modern $S_{\text {deep }}(35.06,34.926$, and 34.893 at BOFS 17,11 , and 14 $\mathrm{K}$, respectively ${ }^{2}$ ) and the term 1.11 is the scaling term for a global $\mathrm{S}-\delta^{18} \mathrm{O}_{\text {global_sealevel }}$ relationship $p^{29,91}$. We assume $\pm 1^{\circ} \mathrm{C}$ and $\pm 1 \%$ uncertainties in $\mathrm{T}_{\text {deep }}$ and $\mathrm{S}_{\text {deep }}$ respectively. Use of other methods to estimate $T_{\text {deep }}$ and $S_{\text {deep }}$ negligibly affects our conclusions, due to relatively weak sensitivities of $\left[\mathrm{CO}_{3}{ }^{2-}\right]_{\text {Norm }}$ to $\mathrm{T}$ and $\mathrm{S}$ changes (Fig. 4).

Uncertainties and statistical analyses. Uncertainties associated with $\left[\mathrm{CO}_{3}{ }^{2-}\right]$ and $\mathrm{PO}_{4}$ were evaluated using a Monte-Carlo approach ${ }^{92,93}$. Errors associated with the chronology ( $x$-axis) and $\left[\mathrm{CO}_{3}{ }^{2-}\right]$ and $\mathrm{PO}_{4}$ reconstructions $(y$-axis) are considered during error propagation. Age errors are assumed to be \pm 3000 years for the three BOFS cores. Methods to calculate errors associated with individual $\left[\mathrm{CO}_{3}{ }^{2-}\right]$ and $\mathrm{PO}_{4}$ reconstructions ( $y$-axis) are given above. All data points were sampled separately and randomly 5000 times within their chronological and $\left[\mathrm{CO}_{3}{ }^{2-}\right]$ or $\mathrm{PO}_{4}$ uncertainties and each iteration was then interpolated linearly. At each time step, the probability maximum and data distribution uncertainties of the 5000 iterations were assessed. Figure 3 shows probability maxima (bold curves) and $\pm 95 \%$ (light gray; 2.5-97.5th percentile) probability intervals for the data distributions, including chronological and proxy uncertainties. For details, see refs. ${ }^{92,93}$.

For a time period (e.g., Holocene) where multiple analyses are available, uncertainties are calculated following the method from ref. ${ }^{94}$ by $2 \sigma=$

$\sqrt{\left[\sum_{i=1}^{n}\left(2 \sigma_{i}\right)^{2}\right] / n}$, where $n$ is the number of reconstructions and $2 \sigma_{i}$ is the error associated with individual reconstruction. For $\left[\mathrm{CO}_{3}{ }^{2-}\right]$ or $\left[\mathrm{CO}_{3}{ }^{2-}\right]_{\mathrm{Norm}}$ offsets

between the Holocene and LGM, $2 \sigma=\sqrt{\left(2 \sigma_{\text {Holocene }}\right)^{2}+\left(2 \sigma_{\text {LGM }}\right)^{2}}$, where $2 \sigma_{\text {Holocene }}$ and $2 \sigma_{\mathrm{LGM}}$ are $2 \sigma$ of Holocene and LGM values, respectively. Other methods (e.g. weighted mean $)^{95}$ would give similar results.

When using Eq. (11) to calculate $\left[\mathrm{CO}_{3}{ }^{2-}\right]_{\text {Norm }}$, errors from various sensitivities are $<1.5 \mu \mathrm{mol} / \mathrm{kg}$ (see Supplementary Data 8 for crosschecking). Because $\left[\mathrm{CO}_{3}{ }^{2-}\right]$ is normalized to a constant condition (i.e., no error with final T-S-P), the error in $\left[\mathrm{CO}_{3}{ }^{2-}\right]_{\text {Norm }}$ is largely sourced from $\left[\mathrm{CO}_{3}{ }^{2-}\right]$ reconstruction uncertainties. For surface water $\left[\mathrm{CO}_{3}{ }^{2-}\right]_{\text {Norm }}$ calculations, $\mathrm{T}$ and $\mathrm{S}$ errors are already included in surface $\left[\mathrm{CO}_{3}{ }^{2-}\right]$ reconstructions. For calculations associated with deep waters, $\left[\mathrm{CO}_{3}{ }^{2-}\right]_{\mathrm{Norm}}$ errors are $\sim 0.5, \sim 3.5$, and $\sim 0.1 \mu \mathrm{mol} / \mathrm{kg}$ from $\pm 1{ }^{\circ} \mathrm{C}$ in $\mathrm{T}, \pm 1 \%$ in $\mathrm{S}$, and $\pm 50 \mathrm{dbar}$ in $\mathrm{P}$, respectively. Therefore, these uncertainties (already included in error calculations) are relatively less important compared to the reconstruction error of $\pm 10 \mu \mathrm{mol} / \mathrm{kg}$ for deep water $\left[\mathrm{CO}_{3}^{2-}\right]$.

\section{Data availability}

The data reported in the paper are presented in Supplementary Data.

Received: 24 October 2018 Accepted: 12 April 2019

Published online: 15 May 2019

\section{References}

1. Takahashi, T. et al. Climatological mean and decadal change in surface ocean pCO2, and net sea-air CO2 flux over the global oceans. Deep Sea Res Part II 56, 554-577 (2009) 
2. Key, R. M. et al. A global ocean carbon climatology: results from Global Data Analysis Project (GLODAP). Glob. Biogeochem. Cycle 18, GB4031 (2004).

3. Broecker, W. \& Peng, T. H. Interhemispheric transport of carbon dioxide by ocean circulation. Nature 356, 587-589 (1992).

4. Gloor, M. et al. A first estimate of present and preindustrial air-sea $\mathrm{CO} 2$ flux patterns based on ocean interior carbon measurements and models. Geophys. Res. Lett. 30, 10-11-10-14 (2003).

5. Ciais, P. et al. Large inert carbon pool in the terrestrial biosphere during the Last Glacial Maximum. Nat. Geosci. 5, 74-79 (2012).

6. Sigman, D. M., Hain, M. P. \& Haug, G. H. The polar ocean and glacial cycles in atmospheric CO2 concentration. Nature 466, 47-55 (2010).

7. $\mathrm{Yu}, \mathrm{J}$. et al. Loss of carbon from the deep sea since the Last Glacial Maximum. Science 330, 1084-1087 (2010).

8. Martinez-Garcia, A. et al. Iron fertilization of the Subantarctic Ocean during the last ice age. Science 343, 1347-1350 (2014).

9. Anderson, R. F. et al. Wind-driven upwelling in the Southern Ocean and the deglacial rise in atmospheric CO2. Science 323, 1443-1448 (2009).

10. Anderson, L. A. \& Sarmiento, J. L. Redfield ratios of remineralization determined by nutrient data-analysis. Glob. Biogeochem. Cycle 8, 65-80 (1994).

11. Keeling, C. D. \& Heimann, M. Meridional eddy diffusion model of the transport of atmospheric carbon dioxide: 2 . Mean annual carbon cycle. $J$. Geophys. Res. 91(D7), 7782-7796 (1986).

12. Toggweiler, J. R., Murnane, R., Carson, S., Gnanadesikan, A. \& Sarmiento, J. L. Representation of the carbon cycle in box models and GCMs: 2. Organic pump. Glob. Biogeochem. Cycle 17, 1027 (2003).

13. Toggweiler, J. R., Gnanadesikan, A., Carson, S., Murnane, R. \& Sarmiento, J. L. Representation of the carbon cycle in box models and GCMs: 1. Solubility pump. Glob. Biogeochem. Cycle 17, 1026 (2003).

14. Palter, J. B., Lozier, M. S. \& Barber, R. T. The effect of advection on the nutrient reservoir in the North Atlantic subtropical gyre. Nature 437, 687-692 (2005).

15. Hain, M. P., Sigman, D. M. \& Haug, G. H. The Biological Pump in the Past. In Treatise on Geochemistry 2nd ed. 485-517 (Elsevier, 2013).

16. Zeebe, R. E. \& Wolf-Gladrow, D. A. $\mathrm{CO}_{2}$ in Seawater: Equilibrium, Kinetics, Isotopes Vol. 65 (Elsevier, Amsterdam, 2001).

17. Talley, L. D. Closure of the global overturning circulation through the Indian, Pacific, and Southern Oceans: schematics and transports. Oceanography 26, 80-97 (2013).

18. Lozier, M. S. Deconstructing the conveyor belt. Science 328, 1507-1511 (2010).

19. Foukal, N. P. \& Lozier, M. S. No inter-gyre pathway for sea-surface temperature anomalies in the North Atlantic. Nat. Commun. 7, 11333 (2016).

20. Johns, W. E., Townsend, T. L., Fratantoni, D. M. \& Wilson, W. D. On the Atlantic inflow to the Caribbean Sea. Deep Sea Res. Part I: Oceanogr. Res. Pap. 49, 211-243 (2002)

21. Foster, G. L. Seawater $\mathrm{pH}, \mathrm{pCO} 2$ and [CO32-] variations in the Caribbean Sea over the last $130 \mathrm{kyr}$; a boron isotope and $\mathrm{B} / \mathrm{Ca}$ study of planktic foraminifera. Earth Planet Sci. Lett. 271, 254-266 (2008).

22. Henehan, M. J. et al. Calibration of the boron isotope proxy in the planktonic foraminifera Globigerinoides ruber for use in palaeo-CO2 reconstruction. Earth Planet Sci. Lett. 364, 111-122 (2013).

23. Curry, W. B. \& Oppo, D. Glacial water mass geometry and the distribution of d13C of SCO2 in the western Altantic Ocean. Paleoceanography 20, PA1017 (2005).

24. Yu, J. M., Elderfield, H. \& Piotrowski, A. Seawater carbonate ion-d13C systematics and application to glacial-interglacial North Atlantic ocean circulation. Earth Planet Sci. Lett. 271, 209-220 (2008).

25. Yu, J. M. \& Elderfield, H. Benthic foraminiferal B/Ca ratios reflect deep water carbonate saturation state. Earth Planet Sci. Lett. 258, 73-86 (2007).

26. Boyle, E. A. Cadmium: Chemical tracer of deepwater paleoceanography. Paleoceanography 3, 471-489 (1988).

27. Boyle, E. A. Cadmium and $\mathrm{d} 13 \mathrm{C}$ paleochemical ocean distributions during the stage-2 glacial maximum. Annu Rev. Earth Planet Sci. 20, 245-287 (1992).

28. Pelletier, G., Lewis, E. \& Wallace, D. A Calculator for the CO2 System in Seawater for Microsoft Excel/VBA, 1.0 ed. (Washington State Department of Ecology, Olympia; Brookhaven National Laboratory, Upton, 2005).

29. Sarmiento, J. L. \& Gruber, N. Ocean Biogeochemical Dynamics. (Princeton University Press, Princeton, 2006).

30. Takahashi, T., Broecker, W. \& Langer, S. Redfield ratio based on chemical data from isopycnal surfaces. J. Geophys. Res. 90, 6907-6924 (1985).

31. Lynch-Stieglitz, J. et al. Atlantic meridional overturning circulation during the Last Glacial Maximum. Science 316, 66-69 (2007).

32. Lynch-Stieglitz, J., van Geen, A. \& Fairbanks, R. G. Interocean exchange of Glacial North Atlantic intermediate water: evidence from Subantarctic Cd/Ca and carbon isotope measurements. Paleoceanography 11, 191-201 (1996).
33. Makou, M. C., Oppo, D. W. \& Curry, W. B. South Atlantic intermediate water mass geometry for the last glacial maximum from foraminiferal $\mathrm{Cd} / \mathrm{Ca}$. Paleoceanography 25, PA4101 (2010).

34. McManus, J. F., Francois, R., Gherardi, J. M., Keigwin, L. D. \& Brown-Leger, S Collapse and rapid resumption of Atlantic meridional circulation linked to deglacial climate changes. Nature 428, 834-837 (2004).

35. Howe, J. N. W. et al. North Atlantic deep water production during the Last Glacial Maximum. Nat. Commun. 711765 (2016).

36. Gebbie, G. How much did Glacial North AtlanticWater shoal? Paleoceanography 29, 190-209 (2014).

37. Keigwin, L. \& Swift, S. A. Carbon isotope evidence for a northern source of deep water in the glacial western North Atlantic. Proc. Natl Acad. Sci. USA 114, 2831-2835 (2017).

38. Johnson, G. C. Quantifying Antarctic bottom water and north atlantic deep water volumes. J. Geophys. Res. Oceans 113, C05027 (2008).

39. Broecker, W. et al. How much deep water is formed in the Southern Ocean? J. Geophys. Reasearch 103, 15833-15843 (1998).

40. Yu, J., Thornalley, D. J. R., Rae, J. \& McCave, I. N. Calibration and application of $\mathrm{B} / \mathrm{Ca}, \mathrm{Cd} / \mathrm{Ca}$, and $\mathrm{d} 11 \mathrm{~B}$ in Neogloboquadrina pachyderma (sinistral) to constrain $\mathrm{CO} 2$ uptake in the subpolar North Atlantic during the last deglaciation. Paleoceanography 28, 237-252 (2013).

41. Martinez-Boti, M. A. et al. Boron isotope evidence for oceanic carbon dioxide leakage during the last deglaciation. Nature 518, 219-U154 (2015).

42. Gray, W. R. et al. Deglacial upwelling, productivity and $\mathrm{CO} 2$ outgassing in the North Pacific Ocean. Nat. Geosci. 11, 340-344 (2018).

43. Liu, Z. et al. Transient simulation of last deglaciation with a new mechanism for Bolling-Allerod warming. Science 325, 310-314 (2009).

44. Waelbroeck, C. et al. Constraints on the magnitude and patterns of ocean cooling at the Last Glacial Maximum. Nat. Geosci. 2, 127-132 (2009).

45. Straub, M. et al. Nutrient conditions in the subpolar North Atlantic during the last glacial period reconstructed from foraminifera-bound nitrogen isotopes. Paleoceanography 28, 79-90 (2013).

46. Marchitto, T. \& Broecker, W. Deep water mass geometry in the glacial Atlantic Ocean: a review of constraints from the paleonutrient proxy $\mathrm{Cd} / \mathrm{Ca}$. Geochem. Geophys. Geosyst. 7, Q12003 (2006).

47. Yu, J. et al. Sequestration of carbon in the deep Atlantic during the last glaciation. Nat. Geosci. 9, 319-324 (2016).

48. Hoogakker, B. A. A., Elderfield, H., Schmiedl, G., McCave, I. N. \& Rickaby, R. E. M. Glacial-interglacial changes in bottom-water oxygen content on the Portuguese margin. Nat. Geosci. 8, 40-43 (2015).

49. Anderson, R. F. et al. Deep-sea oxygen depletion and ocean carbon sequestration during the last ice age. Glob. Biogeochem. Cycle 33, 301-317 (2019).

50. Chen, T. Y. et al. Synchronous centennial abrupt events in the ocean and atmosphere during the last deglaciation. Science 349, 1537-1541 (2015).

51. Jaccard, S. L., Galbraith, E. D., Martinez-Garcia, A. \& Anderson, R. F. Covariation of deep Southern Ocean oxygenation and atmospheric $\mathrm{CO} 2$ through the last ice age. Nature 530, 207-210 (2016).

52. Crichton, K. A., Bouttes, N., Roche, D. M., Chappellaz, J. \& Krinner, G. Permafrost carbon as a missing link to explain $\mathrm{CO} 2$ changes during the last deglaciation. Nat. Geosci. 9, 683-686 (2016).

53. Ferrari, R. et al. Antarctic sea ice control on ocean circulation in present and glacial climates. Proc. Natl Acad. Sci. USA 111, 8753-8758 (2014).

54. Hain, M. P., Sigman, D. M. \& Haug, G. H. Carbon dioxide effects of Antarctic stratification, North Atlantic Intermediate Water formation, and subantarctic nutrient drawdown during the last ice age: diagnosis and synthesis in a geochemical box model. Glob. Biogeochem. Cycle 24, GB4023 (2010).

55. Mehrbach, C., Culberso, C. H., Hawley, J. E. \& Pytkowic, R. M. Measurement of apparent dissociation-constants of carbonic-acid in seawater at atmospheric-pressure. Limnol. Oceanogr. 18, 897-907 (1973).

56. Dickson, A. G. Thermodynamics of the dissociation of boric-acid in synthetic seawater from 273.15K to 318.15K. Deep Sea Res. Part A 37, 755-766 (1990).

57. Lee, K. et al. The universal ratio of boron to chlorinity for the North Pacific and North Atlantic oceans. Geochim. Cosmochim. Acta 74, 1801-1811 (2010).

58. Menviel, L. et al. Poorly ventilated deep ocean at the Last Glacial Maximum inferred from carbon isotopes: A data-model comparison study. Paleoceanography 32, 2-17 (2017)

59. Schmidt, M. W., Spero, H. J. \& Lea, D. W. Links between salinity variation in the Caribbean and North Atlantic thermohaline circulation. Nature 428, 160-163 (2004).

60. Rosenthal, Y., Boyle, E. A. \& Slowey, N. Temperature control on the incorporation of magnesium, strontium, fluorine, and cadmium into benthic foraminiferal shells from Little Bahama Bank: prospects for thermocline paleoceanography. Geochim. Cosmochim. Acta 61, 3633-3643 (1997).

61. Barker, S., Greaves, M. \& Elderfield, H. A study of cleaning procedures used for foraminiferal Mg/Ca paleothermometry. Geochem. Geophys. Geosyst. 4, 8407 (2003) 
62. Yu, J., Elderfield, H., Greaves, M. \& Day, J. Preferential dissolution of benthic foraminiferal calcite during laboratory reductive cleaning. Geochem. Geophys. Geosyst. 8, Q06016 (2007).

63. Manighetti, B., McCave, I. N., Maslin, M. \& Shackleton, N. J. Chronology for climate change: developing age models for the Biogeochemical Ocean Flux Study cores. Paleoceanography 10, 513-525 (1995).

64. Barker, S., Kiefer, T. \& Elderfield, H. Temporal changes in North Atlantic circulation constrained by planktonic foraminiferal shell weights. Paleoceanography 19, PA3008 (2004).

65. Bertram, C. J., Elderfield, H., Shackleton, N. J. \& Macdonald, J. A. Cadmium/ calcium and carbon-isotope reconstructions of the glacial northeast Atlantic Ocean. Paleoceanography 10, 563-578 (1995).

66. $\mathrm{Yu}, \mathrm{J}$. M. \& Elderfield, $\mathrm{H}$. $\mathrm{Mg} / \mathrm{Ca}$ in the benthic foraminifera Cibicidoides wuellerstorfi and Cibicidoides mundulus: temperature versus carbonate ion saturation. Earth Planet Sci. Lett. 276, 129-139 (2008).

67. Yu, J. M., Day, J., Greaves, M. \& Elderfield, H. Determination of multiple element/calcium ratios in foraminiferal calcite by quadrupole ICP-MS. Geochem Geophys Geosyst 6, Q08P01 (2005).

68. Lear, C. H. et al. Breathing more deeply: deep ocean carbon storage during the mid-Pleistocene climate transition. Geology 44, 1035-1038 (2016).

69. Boyle, E. \& Keigwin, L. D. Comparison of Atlantic and Pacific paleochemical records for the last 215,000 years: changes in deep ocean circulation and chemical inventories. Earth Planet Sci. Lett. 76, 135-150 (1985).

70. Foster, G. L. \& Sexton, P. F. Enhanced carbon dioxide outgassing from the eastern equatorial Atlantic during the last glacial. Geology 42, 1003-1006 (2014).

71. Carlson, A. E. et al. Subtropical Atlantic salinity variability and Atlantic meridional circulation during the last deglaciation. Geology 36, 991-994 (2008).

72. Lüthi, D. et al. High-resolution carbon dioxide concentration record 650,000-800,000 years before present. Nature 453, 379-382 (2008).

73. Ziegler, M., Nürnberg, D., Karas, C., Tiedemann, R. \& Lourens, L. J. Persistent summer expansion of the Atlantic Warm Pool during glacial abrupt cold events. Nat. Geosci. 1, 601 (2008).

74. Flower, B. P., Hastings, D. W., Hill, H. W. \& Quinn, T. M. Phasing of deglacial warming and Laurentide Ice Sheet meltwater in the Gulf of Mexico. Geology 32, 597-600 (2004).

75. Rühlemann, C., Mulitza, S., Müller, P. J., Wefer, G. \& Zahn, R. Warming of the tropical Atlantic Ocean and slowdown of thermohaline circulation during the last deglaciation. Nature 402, 511 (1999).

76. Yu, J. et al. Responses of the deep ocean carbonate system to carbon reorganization during the Last Glacial-interglacial cycle. Quat. Sci. Rev. 76, 39-52 (2013).

77. Yu, J., Foster, G. L., Elderfield, H., Broecker, W. S. \& Clark, E. An evaluation of benthic foraminiferal $\mathrm{B} / \mathrm{Ca}$ and $\mathrm{d} 11 \mathrm{~B}$ for deep ocean carbonate ion and $\mathrm{pH}$ reconstructions. Earth Planet Sci. Lett. 293, 114-120 (2010).

78. Rae, J. W. B., Foster, G. L., Schmidt, D. N. \& Elliott, T. Boron isotopes and B/ $\mathrm{Ca}$ in benthic foraminifera: proxies for the deep ocean carbonate system. Earth Planet Sci. Lett. 302, 403-413 (2011).

79. Boyle, E. A., Labeyrie, L. \& Duplessy, J. C. Calcitic foraminiferal data confirmed by cadmium in aragonitic Hoeglundina-application to the Last Glacial Maximum in the northern Indian Ocean. Paleoceanography 10, 881-900 (1995).

80. Schlitzer, R. et al. The GEOTRACES intermediate data product 2017. Chem. Geol. 493, 210-223 (2018)

81. Oppo, D. et al. Data constraints on Glacial Atlantic water mass geometry and properties. Paleoceanogr. Paleoclimatol. 33, 1013-1034 (2018).

82. Came, R. E., Oppo, D. W., Curry, W. B. \& Lynch-Stieglitz, J. Deglacial variability in the surface return flow of the Atlantic meridional overturning circulation. Paleoceanography 23, PA1217 (2008).

83. Elderfield, H. \& Rickaby, R. E. M. Oceanic Cd/P ratio and nutrient utilization in the glacial Southern Ocean. Nature 405, 305-310 (2000).

84. Delaney, M. L. \& Boyle, E. A. Cd/Ca in late miocene benthic foraminifera and changes in the global organic-carbon budget. Nature 330, 156-159 (1987).

85. Jaccard, S. L. \& Galbraith, E. D. Large climate-driven changes of oceanic oxygen concentrations during the last deglaciation. Nat. Geosci. 5, 151-156 (2012).

86. Stanford, J. D. et al. Timing of meltwater pulse 1a and climate responses to meltwater injections. Paleoceanography 21, PA4103 (2006).

87. Lambeck, K., Rouby, H., Purcell, A., Sun, Y. Y. \& Sambridge, M. Sea level and global ice volumes from the Last Glacial Maximum to the Holocene. P Natl. Acad. Sci. USA 111, 15296-15303 (2014).
88. Oppo, D. W. \& Lehman, S. J. Mid-depth circulation of the subpolar North Atlantic during the last glacial maximum. Science 259, 1148-1152 (1993).

89. Rickaby, R. E. M. \& Elderfield, H. Evidence from the high-latitude North Atlantic for variations in Antarctic Intermediate water flow during the last deglaciation. Geochem. Geophys. Geosyst. 6, Q05001 (2005).

90. Marchitto, T. M. et al. Improved oxygen isotope temperature calibrations for cosmopolitan benthic foraminifera. Geochim. Cosmochim. Acta 130, 1-11 (2014).

91. Waelbroeck, C. et al. Sea-level and deep water temperature changes derived from benthic foraminifera isotopic records. Quat. Sci. Rev. 21, 295-305 (2002).

92. Grant, K. M. et al. Rapid coupling between ice volume and polar temperature over the past 150,000 years. Nature 491, 744-747 (2012).

93. Rohling, E. J. et al. Sea-level and deep-sea-temperature variability over the past 5.3 million years. Nature 508, 477-482 (2014).

94. Harris, D. C. Quantitative Chemical Analysis, 6th ed. (W. H. Freeman and Company, New York, 2002).

95. Taylor, J. R. An Introduction to Error Analysis. (University Science Books, Sausalito, California, 1982).

96. Schlitzer, R. Ocean Data View. http://odv.awi-bremerhaven.de (2006).

\section{Acknowledgements}

This contribution is dedicated to W.S. Broecker. We thank R.F. Anderson and Daniel Sigman for the discussions. This work is supported by ARC Future Fellowship (FT140100993) and Discovery Projects (DP140101393 and DP190100894) and NSFC (41676026) to J.Y., DECRA (DE150100107) and Discovery (DP180100048) to L.M., NERC Advanced Fellowship to GLF (NE/D00876X/2), and Australian Laureate Fellowship (FL120100050) to E.J.R.

\section{Author contributions}

J.Y. conceived the idea and wrote the paper. L.M. assisted with the model data used. Z.J./ F.Z. picked the foram shells. E.J.R./Y.D. assisted with the statistics. G.L.F./J.Y. measured the boron isotopes. All authors (L.M., Z.J., D.T., G.F., E.R., N.M., J.M., Y.D., H.R., F.H., F.Z., P.C. and A.R.) contributed to improving the paper.

\section{Additional information}

Supplementary Information accompanies this paper at https://doi.org/10.1038/s41467019-10028-z.

Competing interests: The authors declare no competing interests.

Reprints and permission information is available online at http://npg.nature.com/ reprintsandpermissions/

Journal peer review information: Nature Communications thanks Anne Willem, Omta, Shuang Zhang and the other, anonymous, reviewer(s) for their contribution to the peer review of this work. Peer reviewer reports are available.

Publisher's note: Springer Nature remains neutral with regard to jurisdictional claims in published maps and institutional affiliations.

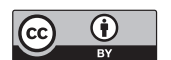

Open Access This article is licensed under a Creative Commons Attribution 4.0 International License, which permits use, sharing, adaptation, distribution and reproduction in any medium or format, as long as you give appropriate credit to the original author(s) and the source, provide a link to the Creative Commons license, and indicate if changes were made. The images or other third party material in this article are included in the article's Creative Commons license, unless indicated otherwise in a credit line to the material. If material is not included in the article's Creative Commons license and your intended use is not permitted by statutory regulation or exceeds the permitted use, you will need to obtain permission directly from the copyright holder. To view a copy of this license, visit http://creativecommons.org/ licenses/by/4.0/

(C) The Author(s) 2019 